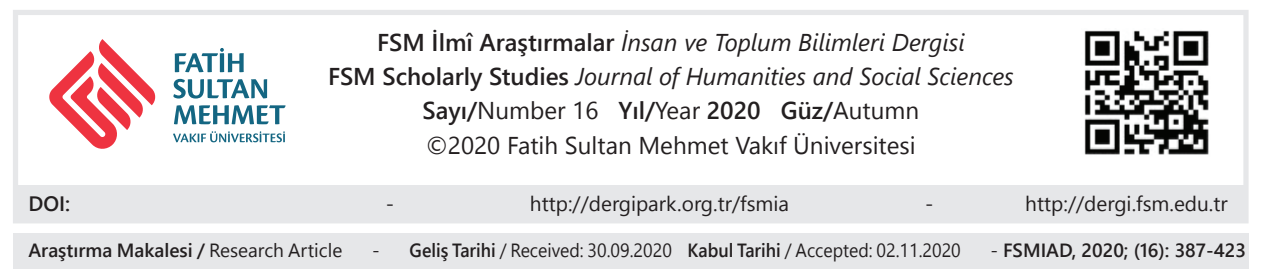

\title{
Kiliseden Camiye Dönüştürme ve İstanbul'da Kiliseden Dönüştürülen Camiler Hakkında Notlar
}

Halil İbrahim Düzenli*

\section{$\ddot{O} z$}

Bir dinin/inancın ibadet ritüellerinin toplu olarak gerçekleştirildiği "kutsal" mekânların başka bir din/inanç ritüelleri için kullanılmaya başlanması, mekânların bu anlamdaki dönüşümleri tarih boyunca karşılaşılan durumlardır. Söz konusu dönüşümlerin coğrafyaya, tarihsel döneme, belli inanç faktörlerine, siyasal iklime, iktidar ilişkilerine vb. göre farklılıklar gösterdiği söylenebilir. Bu makalede bir mesele olarak "kutsal mekânın dönüşümü” ve İstanbul özelinde kiliseden camiye dönüşüm irdelenecektir. Zeyrek Camii (Pantakrator Kilisesi/Manastırı) gibi bazı dönüşümlere ayrıca değinilecektir. İstanbul'daki dönüşümler literatürde farklı sayı ve isimlerde yer almaktadır. Makalede bu literatürün biraraya getirilmesi, bazı tashihler yapılması ve toparlanması amaçlanmaktadır. Bugün İstanbul'da ismi bilinen, halen ayakta veya kaybolmuş olsa da konumları tahmin edilen kırk adet kiliseden çevrilme cami bulunmaktadır. Makalenin temel savı kiliseden camiye dönüştürme eyleminin bütüncül veya tek bir sebebe bağlı olarak açıklanamayacağı, her durumun/tekil örneğin farklılıklar barındırdığıdır. Kiliseler bir gayr-i müslim memleketini fethetmenin sembolü olarak, ilâhi nizamın yeniden tesisi için, demografik yapı değişimlerine bağlı olarak, harap olan yapıların ihtiyaç doğrultusunda yeniden kullanımı gibi nedenlerle camiye çevrilmiştir.

Anahtar Kelimeler: Cami, kilise, dönüşüm, İstanbul, Zeyrek Cami.

* $\quad$ Dr. Öğr. Üyesi, Samsun Üniversitesi Mimarlık ve Tasarım Fakültesi Mimarlık Bölümü, Samsun/Türkiye, halilibrahim.duzenli@samsun.edu.tr, orcid.org/0000-0002-7566-5926 


\title{
Transforming Churches into Mosques and Notes on Converted Churches in Istanbul
}

\begin{abstract}
The transformation of "sacred" places where the rituals of worship belonging to one religion/faith are used to be performed collectively in order for the use of rituals belonging to another religious/faith is frequently encountered throughout history. It can be said that these transformations vary according to geography, historical period, certain belief factors, political climate, power relations, and etc. This article will discuss the "transformation of a sacred place" as an issue in general and the transformation of a church into a mosque in Istanbul in particular. Some transformations, such as the Zeyrek Mosque (the Church of the Monastery of Christ Pantokrator), will be discussed separately. Such transformations in Istanbul are cited in different numbers and names in literature. In this article, it is aimed to combine this literature, making some revisions and collecting together. Today, there are forty mosques in Istanbul, which have been converted from churches whose names are known, some of which are still surviving while others are lost but with the predicted locations. The main argument of the article is that the action of transforming from church into mosque cannot be explained solely grounded upon a holistic or single cause, and that each situation/single example contains differences. Churches have been transformed into mosques for reasons such as a symbol of conquering a non-Muslim country, re-establishing the divine order, or re-use of ruined structures due to the needs emerging depending on the demographic changes.
\end{abstract}

Keywords: Mosque, converted church, transformation, Istanbul, Zeyrek Mosque. 


\section{Giriş}

Bir kutsal mekanın, yine kutsal mekan işlevini sürdürerek, başka bir inancın mekanına dönüştürülmesi meselesi kuşkusuz en netameli konulardan biridir. İnsanlık tarihi boyunca farklı zaman ve yöntemlerle gerçekleşen bu hadiseler insanlık tarihinin ortak bir mirası gibidir. Pagan mekanların başka pagan tapınaklarına, bunların Hristiyan mekanlarına, Hristiyan mekanların Müslüman mekanlarına, Müslüman mekanların Hristiyan mekanlarına dönüşümü farklı yüzyıllarda cereyan eden sosyal, politik, dini değişim ve dönüşümlerin bir sonucudur. Konu hakkındaki değerlendirmeler politik, dini, sosyal konumlarına göre konuşan ve yazan insanların durdukları yer ve baktıkları dünya görüşüyle alakalıdır.

Yorumlarda ayrışma ve farklılaşmalar bununla da bitmemektedir. Mesleki pozisyonlar ile odaklanılan alt konu (sanat, mimari, siyasi tarih vb.) değiştikçe yorumlar da çeşitlenebilmektedir. Örneğin, "Akdeniz Medeniyetleri” kuramcısı ve Akdeniz medeniyetlerinin geçişkenliklerine olan vurgularılyla bilinen tarihçi Fernand Braudel, Endülüs Emevi dönemi mimari eseri olan Kurtuba Ulu Camii'ne eklenmiş olan Santa Cruz Kilisesi'ni "sevimli, küçük, gotik bir kilise" diye tarif ederken, ${ }^{1}$ meseleye eserin yüksek sanat değeri penceresinden bakan mimar Turgut Cansever aynı yapıyı "Kurtuba Ulu Camii'nin yüksek değerine bir tecavüz ve kaba saba bir müdahale" olarak tanımlamaktadır. ${ }^{2}$

Dini ve siyasal pozisyon alışların bir örneğine ise İstanbul bağlamında yer verilebilir. İstanbul'da camiye çevrilen kiliselerin sayılarının çokluğu ve azlığ meselesiyle ilgili olarak, olası ihtiyat kayıtları düşülerek, Stefanos Yerasomos'un tespit ve yorumları bir açıklama sunmaktadır:

"Bu konudaki tartı̧̧manın nedeni ise 18. yüzyıldan kalma. Mesela 18. yüzy1lda ilk İstanbul camileri ansiklopedisini yapan Hüseyin Ayvansarayi, birçok caminin kiliseden çevrilmiş olmasını ister ve yazar. Kiliseleri camiye çevirmek bir Müslüman için sevap olduğundan kiliseden camiye çevrilen binaların sayısını artırmak ister. Bunu, aksine bir nedenle o dönemdeki İstanbul Rum cemaati de sahiplenir. Mesela Patrik Konstantios'un 1840 civarıda yazdığ 1 Konstantinias adlı eserinde ve ondan sonra gelen İstanbullu Rum yazarlar da, kiliseden camiye çevrilen binaların sayısını bir bakıma artırmak isterler, çünkü böylelikle birçok görkemli binanın ilk durumunu sahiplenmiş olacaklardır. Yabancı yazarlar ve seyyahlar da bu sayıyı yüksek tutarlar, çünkü bunlar 17.-18. yüzyılda İstanbul'a gelip camileri Aya-

1 Fernand Braudel - vd., Akdeniz, Mekan ve Tarih, çev. N. İ. Erkurt, 2. bs., İstanbul, Metis Yay1nlar1, 1995, s. 111.

2 Turgut Cansever, "Doğu ve Batı İlişkilerine Bir Bakış”, Doğu Batı, sayı 2, 1998, s. 148-149. 
sofya'ya benzer bir biçimde gördüklerinde, çoğu zaman "herhalde bunlar da kiliseden çevrilmiştir” diye düşünürler ve yazarlar. Kısacası çok çeşitli nedenlerden dolayı böyle bir eğilim oluşur. Bu eğilim 20. yüzyılda tersine çevrilir. Türkiye Cumhuriyeti'nin ilk sanat tarihçileri daha fazla binanın özgün olduğunu ve kiliseden çevrilme olmadığını kanıtlamak ister. Mesela Fatih dönemi mimarisini yazan Ekrem Hakkı Ayverdi bu konuda çok 1srar eder ve binaların çoğunun özgün olduğunu ispat etmek ister. Bugün bu işin biraz uzmanı olan kişi hangi bina eskiden Bizans yapısıydı hangisi değildi diye anlamakta zorluk çekmez. Oysa bu tartışmanın hâlâ devam eder gibi bir hâli var."3

Bu makale açısından, Yerasimos'un bu kadar keskin ve etkili bir üslupla dile getirdiği meselelerin, doğru ve yanlışlıklarından çok bir sorunsal olarak ortaya konulmaları önemlidir. Söz gelimi, Ekrem Hakkı Ayverdi’nin kaç kiliseyi Osmanlı eseri olarak tavsif ettiği başka bir tartışma ve yazının konusudur.

Yerasimos 18. yüzyıldan başlayan ve tarihsel olarak hala devam eden tartışmalardan bahsetmektedir. Peki, bu karmaşık ve olası pozisyon alışlar arasında bir kilisenin camiye dönüştürülmesi meselesine nasıl yaklaşmak gerekir? Öncelikle, tarihsel süreçte her dönem, devlet ve de mimari yapı özelindeki uygulamaların biricikliğine, birbirinden farklı ve karmaşık boyutları olduğuna vurgu yapmak gerekir.

Her şeye rağmen bazı genellemelerde bulunulacak olursa; kiliseden camiye dönüşüm, bir gayr-i müslim memleketini fethetmenin sembolü olarak camiye çevirme, "ilâhi nizamın yeniden tesisi" için dönüştürme, demografik yapı değişimlerine bağlı olarak dönüştürme, harap olan yapıların ihtiyaç doğrultusunda yeniden kullanımı ve sair sebepler ile her bir sebebin ayrı ayrı tanımlanabilecek alt dinamiklerinin toplamı olarak karşımıza çıkmaktadır. Karmaşık boyutlar yüzyıllara ve zaman değişimlerine göre üzerlerine farklı katmanlar da alabilmektedir. Bu bağlamda 15. yüzyıl Osmanlı İstanbul'una odaklanmak mesele hakkında Osmanlı'nın bir anlamda "kurucu pratiklerinin” oluşumu açısından daha manidar görünmektedir. Kutsal mekana yaklaşım, algılama biçimleri ve müdahale usulleri ayrıca incelemeye değer konulardır.

\section{Fetih ve Camiye Dönüştürme}

"Bu şanlı Fetih; müşarünileyh Sultana (cümle duaiye müyesser olunca bu ihsanın bu zahirenin şükrünü eda ve izdiyadını reca ederek murassa' ve müzeyyen

3 Stefanos Yerasimos “Kostantiniyye Kiliselerinden İstanbul Camilerine Bir Değişimin Tarihi”, Bizans: Yapılar, Meydanlar, Yaşamlar, ed. Annie Pralong, çev. Buket Kitapçı Bayrı, İstanbul, Kitap Yayınevi, 2011, s. 182-183. 
ve lâtif keniseleri medreseler mescitlere tahvil etti sonra Cenab-1 Peygamberin vakfiyede yazılı 'Her kim Allah rızası için bir mescit bina eder ise Allah onun için cennete bir ev bina eder' mealindeki hadisi şerifi ile amel ederek onlardan başka olarak yeniden bina etmeğe arzu edip mezbûr beldede mürtefi' ve merğup mevzi'de bütün kemal ve istihsanı cem' eden ve bânisini cehenneme duhulden men'eden ve cennete duhule müstahik ve nîrandan müsteb'ad k1lan ve bünyânı takva ve rıdvan üzerine müesses ve ahvâl-i cinânı hâki ve ehl-i küfür ve tuğyanın ğam ve gussalarına bâdî bir cami-i şerif bina etti ve vakfiyede yazılı beyitleri haliften işitti." (Fatih Vakfiyesi)

Fetih, "açma, yol gösterme, hüküm verme, galibiyet ve zafere ulaştırma" anlamlarına sahip bir Arapça kelime. Kelimenin, meşru savaşlar sonucunda Müslümanların gayrimüslimlerden gerçekleştirdikleri toprak kazanımlarını diğer "istila" ve "sömürü savaşları"ndan ayırmak amacıyla kullanıldığı ifade edilir. ${ }^{4}$

Türkiye Selçukluları'nda fethi bir metoda dönüştüren yönetici olarak tavsif edilen I. Mesut, yeni şehirlerin kuruluşuna ön ayak olmuş, fethedilen yerleri merkezle bütünleştirme çabasının bir sonucu olarak yolların güvenliği ve ticaretin canlanması için menzil kervansarayları inşa ettirmiştir. Yerli unsurlar ve Bizans'tan danışman ve müşavirlere devlet yönetiminde yer vermek de onun bazı uygulamaları arasındadır. ${ }^{5} \mathrm{Bu}$ tür uygulamalar tarihsel olarak daha önce ve başka İslam bölgelerinde de söz konusu olabilir. Bazı şehirlerin fetih öykülerine kısaca yer vermek gerekirse, İbn Bibi'ye göre, Antalya'nın fethinde, fetih alâmeti olarak kalenin en yüksek yerine sultanın sancağı, diğer burçlara Selçuklu bayrakları dikilmiştir. Kale onarılmış, şehre vali ve subaşı, kadı, hatip, imam, müezzin ve hafızlar tayin edilmiş, çeşitli dinî ve sosyal amaçlı eserler inşa edilmiştir. Sinop'un alınışında yine kaleye saltanat bayrağı dikilmiş, şehrin güvenliği sağlanmış, ayrılmak isteyenlere izin verilmiş, savaş sırasında kaçmış olanlar geri çağrılmış ve mülkleri iade edilmiştir. Ardından Anadolu'nun her beldesinden zengin ve güçlü kimseler Sinop'a getirilerek yerleştirilmiştir. Bir kilise ise camiye çevrilmiştir. Bu metodun daha sonra Osmanlılar'a da model olduğu söylenmektedir. ${ }^{6}$ Osmanl1 fetihlerinde ise, neredeyse sistemli olarak uygulanan safhaların varlığından bah-

4 Mustafa Fayda, "Fetih", İslam Ansiklopedisi, cilt 12, İstanbul, Türkiye Diyanet Vakfi, 1995, s. 467. Bu meselelere ve devamındaki örneklere daha önce şurada yer verilmişti: Ömer İskender Tuluk - Halil İbrahim Düzenli - Evrim Düzenli, “Osmanlı'da Fetih Sonrası Dinsel Mekânı Camileştirme Anlayış1: Trabzon Örneği (1461-1665)”, Trabzon Kent Mirası: Yer Yapı Hafiza, ed. Ömer İskender Tuluk - Halil İbrahim Düzenli, İstanbul, Klasik Yayınları, 2010, s. 93-118.

5 İlhan Erdem, “Türkiye Selçuklularında Fetih Metodu ve Uygulanışı”, I. Uluslararası Selçuklu Kültür ve Medeniyet Kongresi Bildirileri, cilt 1, Konya, 2011, s. 303.

6 Erdem, a.g.t., s. 306-308. 
sedilir. ${ }^{7}$ Osmanlının, kuruluşundan İstanbul'un fethine kadar olan dönemdeki her fetih sonrası uygulama, önceki milletten arda kalan eserlere karşı tavırlar fetih sembolü olarak bir kilisenin camiye çevrilme noktasında ortaklık göstermekte; diğer kilise ve yapılara karşı tavırlar ve mimari tercihler ise duruma göre çeşitlenebilmektedir. ${ }^{8}$ İstanbul'un fethinde, Fatih Sultan Mehmet fethin ikinci günü en önemli kilise olan Ayasofya'ya gider, kilise camiye çevrilir ve şehrin bir İslam şehri oluşuna dair ilk duayı yapar. ${ }^{9}$

Mimarlık tarihi, "mimari”nin tarihin birçok döneminde bir "uygarlık ve dini sembol" aracı olarak görülüp uygulandığı örneklerle doludur. Bu "sembolik temsil anlayışı" özellikle anıtsal dinî yapılarda çok daha egemen ve etkili bir biçimde ifade bulmuştur. Tarihin birçok döneminde çeşitli zaman dilimlerinde el değiştiren bu dinsel yapılar -eğer ideolojik bir art niyet yoksa- çoğunlukla egemen toplumun dinsel sembolü olmaya devam etmiştir.

Bizans kültürünün biçimlendirdiği İstanbul Ayasofya'sı "dinsel sembol" olma niteliğini şehrin fethinden sonra da sürdüren yapılar arasında hiç şüphesiz en önemlisidir. İstanbul'un fethinden hemen sonra camiye çevrilerek ilk cuma namazının burada kılınması, çoğunlukla, Osmanlıların "bir memleket veya kale fethedildiğinde şehrin en büyük kilisesinin (ya da ibadethanesinin) camiye çevrilme geleneği"’nin bir tezahürü olarak yorumlanmıştır. ${ }^{10} \mathrm{Bu}$ anlamıyla, Ayasofya, İstanbul mimarlık tarihinin ete kemiğe bürünmüş ve de bugüne ulaşmış en önemli unsurları arasındadır. Bir başka deyişle, "kadim" olanın en nadide temsillerinden biridir. Hem Bizans'ın hem de Osmanlı'nın mimarlık tarihi boyunca bir referans ve kıyas noktası olarak şehrin mimari tekâmülüne etki etmiş ve her dönemin yeni aktörleri eliyle her dem yeniden biçimlenmiş ve anlamsal olarak "çoğaltılmıştır". Öyle ki, Osmanlı mimarisinde İstanbul'un fethine ve Ayasofya ile karşılaşmaya kadar, bugün çok doğal bir şekilde Osmanlı mimarisi terkibinin ana karakteristik ögelerinden görülebilecek yarım kubbe uygulamasının örneği yoktur. İlk uygulama Fatih Cami ile fetih sonrasındadır. Bir taraftan kadim olanı, Bizans mimarisini tetkik eden ve önyargısız biçimde temellük eden, diğer taraftan Osmanlı'nın yeni mimari terkibinin baş aktörü olan Mimar Sinan için Ayasofya, her

7 Halil İnalc1k, “Ottoman Methods of Conquest”, Studia Islamic, cilt II, 1954, s. 103-129; Halil İnalc1k, “Osmanlı’da Fetih Yöntemleri”, çev. H. C. Tuncer, Cogito, say1 19, 1999, s. 115.

8 Ayrıntılar için bkz.: Doğan Kuban, Osmanlı Mimarisi, İstanbul, Yapı Endüstri Merkezi Yayınlar1, 2007, s. 58-59 ve 165 .

9 Halil İnalcık, “İstanbul: Bir İslam Şehri”, çev. İbrahim Kalın, İslam Tetkikleri Dergisi, İstanbul Üniversitesi Edebiyat Fakültesi Yayını, 1995, s. 247.

10 Semavi Eyice, “Ayasofya”, Istanbul Ansiklopedisi, cilt 1, İstanbul, Tarih Vakfı Yayınları, 1993, s. 448. 
daim iyi bir öğretmen, güzelleştirilmesi gereken bir kadim miras ve yarışılması / geçilmesi gereken bir motivasyon kaynağ 1 idi.

Bugün Ayasofya'ya rafine gözlerle bakıldığında yapı, son derece kıymetli başka bir şeyi anlatmaktadır. Kurulum itibariyle 360 yılından 2020 yılına kadar olan aralıkta "kadim" olan kültürel mirasa her müdahaleyi bizzat onda ve yakın çevresinde gözlemlemek ve şehrin mimarlık serüvenini buradan duyumsamak mümkündür. Ayasofya, form olarak bilinebilen 537 y1lından 21. yüzyıla kadar çeşitli eklentiler ve onarımlarla hayatını sürdürmüştür. ${ }^{11}$
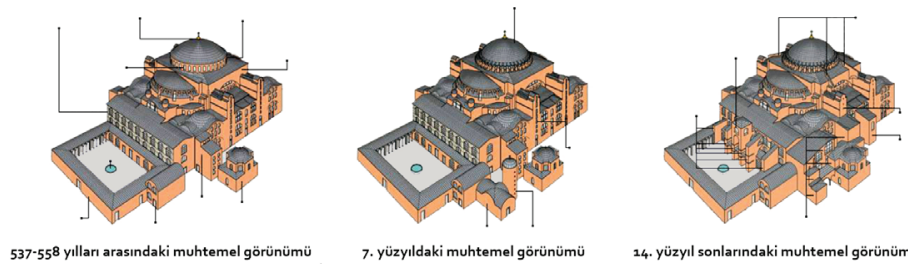

537-558 yılları arasındaki muhtemel görünümü

7. yüzylldaki muhtemel görünümü
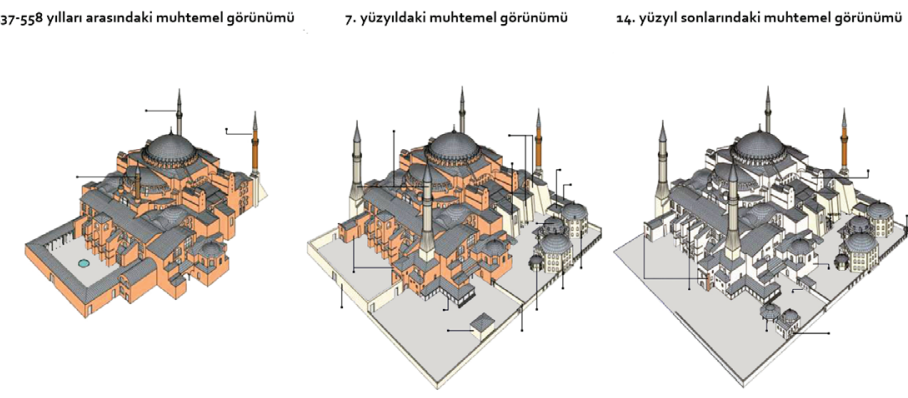

15. yüzyıl sonlarındaki muhtemel görünümü

16. yüzyıl sonlarındaki muhtemel görünümü

18. yüzyıl ortalarındaki muhtemel görünümü
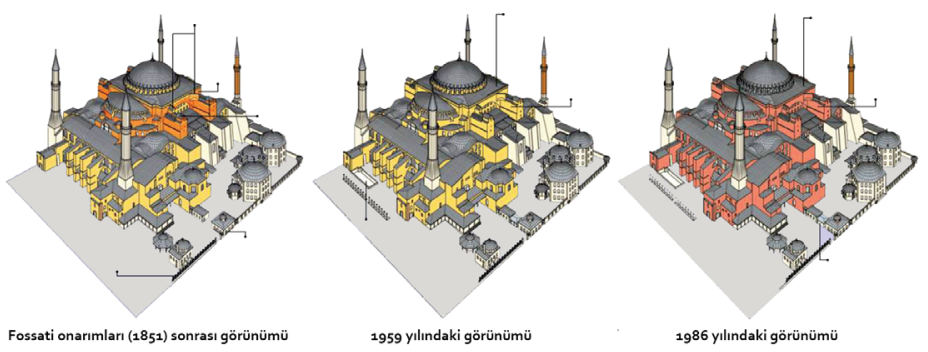

Resim 1. Ayasofya'nın 6. yüzyıl-20. yüzyıl aralığındaki dönüşümlerini gösteren hipotetik perspektif restitüsyonlar1 ${ }^{12}$

11 Ayrıntılı bilgi ve nitelikli bir analiz için bkz.: Hasan Fırat Diker, Ayasofya ve Onarımları, İstanbul, Fatih Sultan Mehmet Vakıf Üniversitesi Yayınları, 2016.

12 Resimler Hasan Fırat Diker'in çalışmasından alınmış ve bir araya getirilmiştir. Yayın izni için teşekkür ederim. Diker, Ayasofya ve Onarımları. 
Fatih döneminde camiye çevrildiğinde eklenen ahşap minare daha sonra y1kılmış, yapıya, (konu hakkında tartışmalar olsa da) biri Fatih, diğeri II. Bayezid devrinde, ikisi de Mimar Sinan tarafından II.Selim-III.Murad devrinde olmak üzere dört minare eklenmiştir. Bu minarelerle ilgili Turgut Cansever'in yorumu şöyledir: "Sinan'ın tasarımı olan ve önceki iki minare ile kıyaslanmayacak kadar kalın gövdeli iki minare, yapıyı batı yönünde âdeta zemine bağlayan iki güçlü odaktır ve daha önce yapılmış narin iki minarenin Ayasofya'ya kazandırdığı doğuya yönelme ifadesini, başka bir ifadeyle, doğuya uzanan bir yarımada üzerinde olduğu gerçeğini daha okunaklı hale getirerek yapıyı bulunduğu yerle bütünleştirmiştir." Cansever'e göre tıpkı minareler gibi istinat duvarları da yapının karakterine "kaba saba bir müdahale" değil onun, şehrin ziyneti olma noktasındaki kadim konumunun bu "yeni”" İslam şehrinde de tahkim edilmesidir: "Ayasofya, yarımadanın müstesna bir noktasında, iç yapısındaki çelişkileri, dışta iri duvarlarının yığınsal ifadesi içinde tek başına duruyorken, Osmanlı mimarlarının ilave ettiği istinat duvarlarıyla biçim çeşitliliği ve Sinan'ın inşa ettiği minarelerin özel ölçüleriyle yeni bir anlam kazanmış, dört minareyle çevrelenmek suretiyle yalnızlığ sona erdirilmiş ve şehrin bir ziyneti seviyesine yükseltilmiştir." Ayasofya'nın hemen yanına yapılan türbe ilaveleri benzer tavrın sürdürülmesidir: "Sinan'ın Ayasofya'daki bu tavr1, 1570'lerde Sultan II. Selim ve daha sonra Sultan III. Murad ve III. Mehmed'in türbelerinin Ayasofya'nın yanına inşa edilmesi kararıyla sürdürülmüştür. Ayasofya, Osmanlılar'ın kendilerinden önceki bir kültüre ve Hristiyanlık eserlerine saygıyla yaklaştıklarının delili olarak, yaptıkları ilavelerle hem korunmuş, hem de bu ilavelerin tamamlayıcı, yüceltici, tezyin edici güzelliğiyle daha değerli hâle getirilerek günümüze ulaşması sağlanmıştır". ${ }^{13}$ Mimar Turgut Cansever' in "kendilerinden önceki bir kültüre ve Hristiyanlık eserlerine saygıyla yaklaştıkları" ifadeleri, Fatih Vakfiyesi'nde kiliselerin "murassa' ve müzeyyen ve lâtif" şeklindeki anlatımlarında karşıllk bulmuş gibidir. Meseleye daha çok sanat değeri bakımından yaklaşan Cansever dışında, söz konusu Osmanlı eklerinin, daha "pragmatik" gerekçelerle açıklandığı, daha çok "iktidarın” dönüşümüyle ilişkilendirildiği çalışmalar ayrıca zikredilmelidir. ${ }^{14}$

13 Turgut Cansever, Mimar Sinan, İstanbul, Albaraka Türk Yayınları, 2005, s. 349.

14 Konu hakkındaki iki çalışma için bkz.: Gülru Necipoğlu, "The Life of an Imperial Monument: Hagia Sophia After Byzantum", Hagia Sophia from the Age of Justinian to the Present, ed. R.Mark - A.Ş.Çakmak, Cambridge University Press, 1992; Hasan Furat Diker, "Ayasofya: Bir İktidar Öyküsü”, İnci Aslanoğlu için Bir Mimarlık Tarihi Dizimi, ODTÜ Yayınları, 2019. 

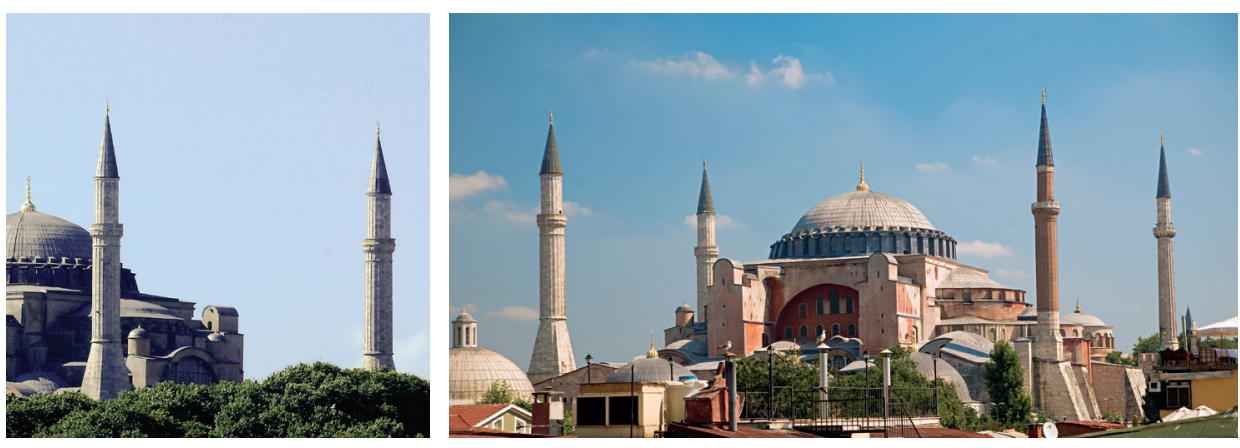

Resim 2-3. Mimar Sinan'ın eklediği Ayasofya minareleri ${ }^{15}$

İstanbul Ayasofya'sının dışında, bu geleneğin uygulanışını 1456'da fethi gerçekleştirilen Atina'daki Parthenon tapınağında ya da 1461'de fethedilmiş Trabzon'daki Panagia Hırisokephalos Kilisesi'nde de görmek mümkündür. ${ }^{16}$ Antikitenin çok tanrılı inanç abidelerinin en önemlilerinden birisi olan Atina Akropolü'ndeki Parthenon tapınağı, pagan kültürüyle başlayan dinî mekân serüvenini, Hristiyan ve Müslüman kültürler içerisinde de sürdürmesi nedeniyle ilginç bir yapıdır. Tapınak (M.Ö. 448-432), M.S. 4. yy.da Iustinianus döneminde kiliseye dönüştürülmüş, Mayıs 1456'da Osmanlılar'ın şehri ele geçirmesinin hemen ardından bir minare eklenerek camiye çevrilmiştir. Daha sonra, 1687 y1lındaki Venedik saldırısıyla harap olan yapıdan elde edilen devşirme malzeme ile yapının ortasına küçük ve tek kubbeli bir "mescid” inşa edilmiştir. Bu dönüştürme diğer mimari uygulamalardan farklılık arzetmektedir ve bazı araştırmacılarca üzerinde durulmuştur. ${ }^{17}$

15 Resim 2: Emine-Mehmet Öğün. Resim 3: Fotoğraf şu çalışmada yayınlanmıştır: Coşkun Yı1maz, ed., Antik Çăg'dan XXI. Yüzyıla Büyük İstanbul Tarihi, cilt 1-10, İstanbul, İSAM ve İBB Kültür AŞ. Yayınları, 2015. Yayın izni için Coşkun Yılmaz'a teşekkür ederim.

16 Ayrıntılar için bkz.: Tuluk vd., a.g.m.

17 Machiel Kiel, “Atina”, İslam Ansiklopedisi, cilt 4, İstanbul, Türkiye Diyanet Vakfı Yayınları, 1991, s. 74; Kemal Kutgün Eyüpgiller, “Atina Akropolü’nde Bir Cami”, Arredamento Mimarlı, say1 173, 2004, s. 118-221. Frederick William Hasluck, Sultanlar Zamanında Hıristiyanlık ve İslam, çev. Timuçin Binder, cilt I, İstanbul, Ayrıntı Yayınlar1, 2012, s. 2022-. 


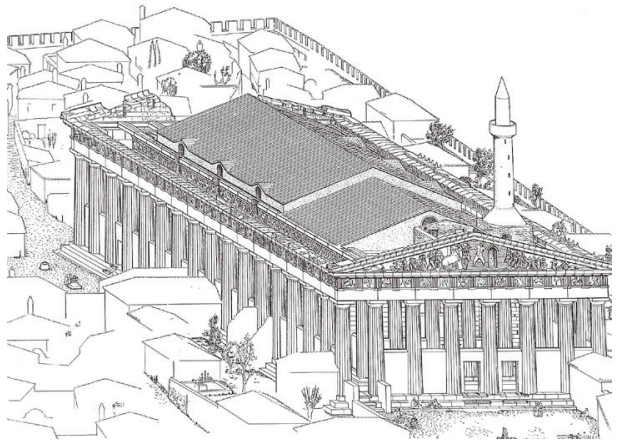

Resim 4. Atina "Cami-i Kebir" $i^{18}$

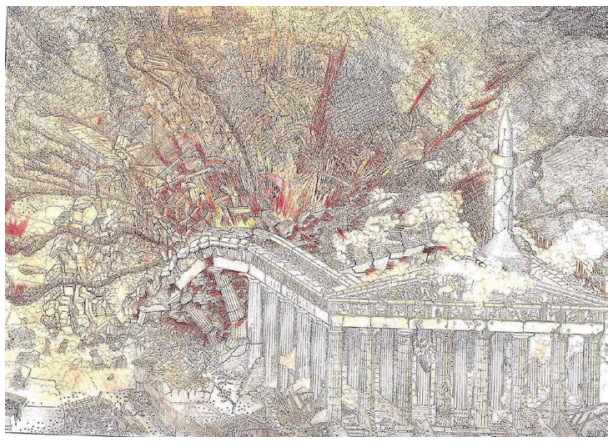

Resim 5. 1687 Venedik Saldırıs1 ${ }^{19}$

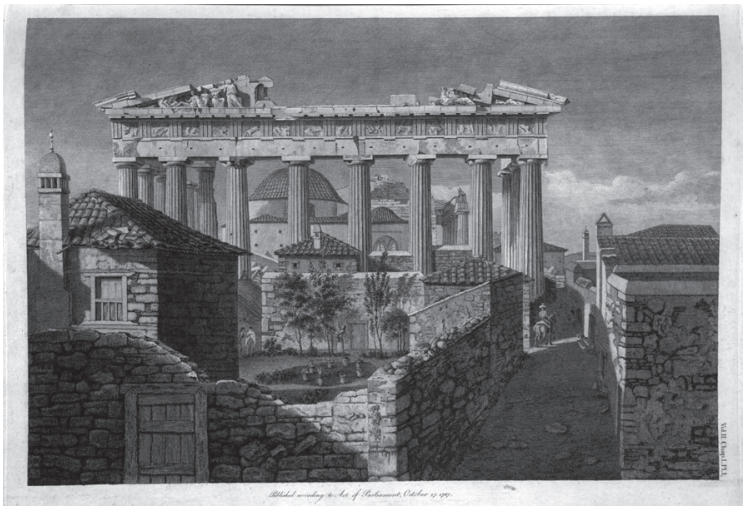

Resim 6. Venedik saldırısı sonrası inşa edilen $\operatorname{mescid}^{20}$

Trabzon'da fetihten hemen sonra camiye dönüştürülen Panagia Hırisokephalos da Bizans Trabzon'unun en büyük kilisesi konumundaydı, sur içinde yer alıyordu. Bu kilise de yine Osmanlı'nın fetih geleneği içinde camiye dönüştürülmüştür (Bugünkü adı Fatih Büyük Cami). Şehrin Osmanlılarca fethedilerek $P a$ nagia Hırisocephalos Kilisesi'nin "Cami-i Atik" adıyla camiye çevrildiği 1461 ile kentin piskoposluk kilisesi Agios Filippos'un camiye dönüştürüldüğü 1665 yılları arasında camiye / mescide dönüştürülen yedi adet kilise/şapel vardır. ${ }^{21}$ Yaklaşık 200 yılda yedi kilisenin camiye dönüştürülmesi meselenin fetih sembolü dışında başka gerekçeleri ve süreci olduğunun göstergesidir.

18 Mimar Manolis Korres'in 1987 tarihli çizimi.

19 Mimar Manolis Korres'in 1987 tarihli çizimi.

20 James Stuart - Nicholas Revett, The Antiquities of Athens (Measured and Delineated by James Stuart F.R.S. and F.S.A. and Nicholas Revett, Painters and Architects), vol. 2, London, John Nichols Publ., 1787, (Vol.II, Chap.I, PL.I).

21 Tuluk vd., a.g.m. 


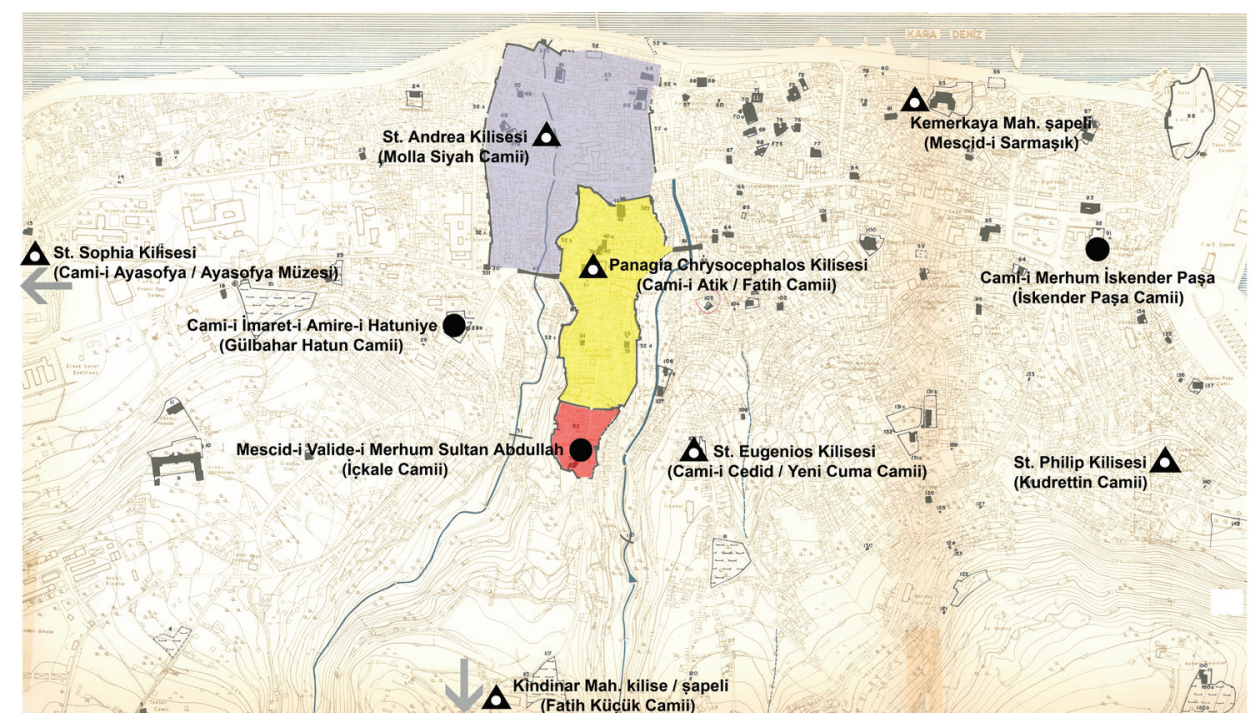

Resim 7. 1461-1665 yılları arasında Trabzon'da camiye / mescide dönüştürülen kilise / şapeller ve inşa edilen bazı Osmanlı cami ve mescitleri ${ }^{22}$
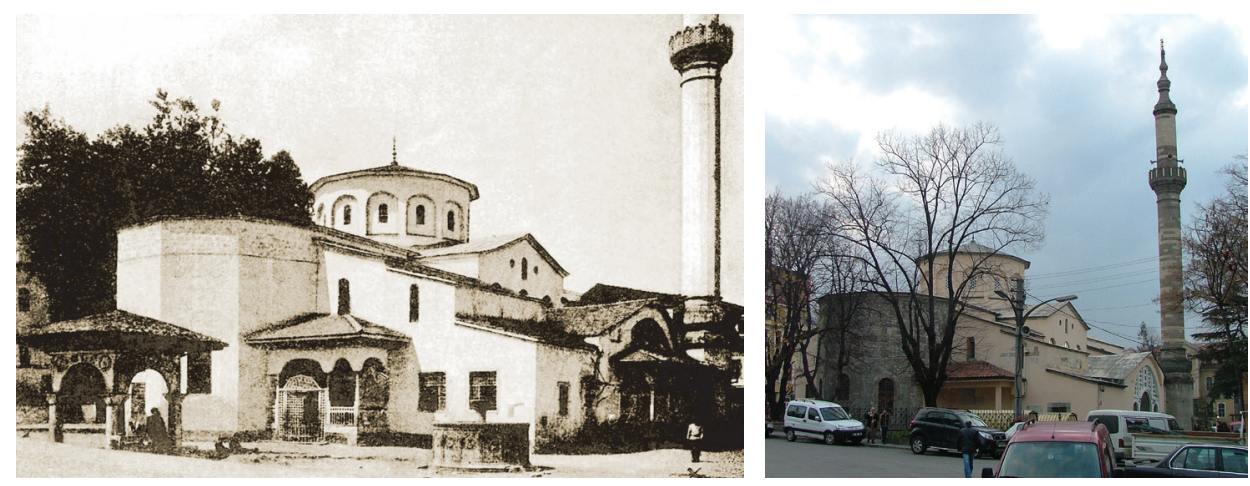

Resim 8-9. 1917'de Trabzon "Cami-i Atik"i23; 2008 y1lında Trabzon Fatih Büyük Camii (F.: Halil İbrahim Düzenli)

Konuyla ilgili literatürde, "Osmanlı'da fetih sonrası kentin en büyük dinî mekânının camiye dönüştürülme anlayışının bir fetih geleneği olduğu” ifadesi artık bir genel kabul gibidir. ${ }^{24}$ Bunun dışında bir ayrıntı bulmak epeyce zahmetlidir. Fe-

22 Tuluk vd., a.g.m.

23 Atilla Bölükbaşı, Anılarda Trabzon, 2 cilt, Trabzon, Serander Yayınları, 2006.

24 Semavi Eyice, “İstanbul'un Camiye Çevrilen Kiliseleri”, TAÇ, cilt 1, sayı 2, İstanbul, Türkiye Anıt Çevre Turizm Değerlerini Koruma Vakfı Yayını, 1986, s. 9-18; Süleyman Kırımtayıf, Converted Byzantine Churches in İstanbul, İstanbul, Ege Yayınları, 2001; Süleyman Kırım- 
tih sonrasında bir kilise ya da şapel camiye ya da mescide çevrilirken yapıya ne tür ekler yapılarak ya da yapıdaki İslam dışı hangi öğeler ortadan kaldırılarak mekânın İslami bir karaktere kavuşturulduğu sorusuna yoğunlaşan çalışmalar azdır. ${ }^{25} \mathrm{Fe}-$ tih sonrası değişen demografik yapının, camiye ya da mescide çevrilen kiliselerin ya da şapellerin seçimindeki etkisi nadiren sorgulanmıştır. Diğer taraftan, camiye çevrilen kiliselerin bina tarihleri, tarihlendirmeleri, koruma sorunları, restorasyon süreçleri ile ilgili monografik nitelikte çalışmalar son yıllarda çoğalmaktadır. ${ }^{26}$

\section{İstanbul'da Kiliseden Camiye Dönüştürülen Yapılar: Kırk Kilise/Kırk Cami}

"Mes'ele: Merhûm Sultân Mehmed Hân ‘aleyhi'r-rahmeti ve'l-gufrân hazretleri, mahrûse-i İstânbûlı ve etrafinda olan karyeleri 'anveten feth mi itmişdür? (Rahmetli Sultan II. Mehmed Hazretleri İstanbul şehrini ve etrafindaki köyleri zor kullanarak mı fethetti?)

El-Cevab: Ma'rûf olan 'anveten, kenâyis-i kadîme hâli üzerine ibkâ olınmak sulhle fethe delâlet ider. Sene hamse ve erba'în ve tis'a mi'e târîhinde bu husûs teftiş olınmışdur. Yüz on yidi yaşında bir kimse bulunup ve yüz otuz yaşında bir kimse dahî bulunup, Yahûdi ve Naşâra el altından Sultân Mehmed ile ittifâk idüp, anlar tekfûra nusret itmiyecek olup, Sultân Mehmed dahî anları seby itmeyüp, halleri üzre mukarrer idicek old1, bu vechile feth olındı diyü müfettiş mahzarında şehâdet idüp, bu şehâdet ile kenâyis-i kadîme hâli üzre kalmışdur." (Ebussuud Efendi) ${ }^{27}$

tayıf, "Fatih Sultan Mehmed ve II. Bayezid Dönemlerinde Cami veya Mescide Dönüştürülen Bizans Yapıları", Sanat Tarihi Defterleri 7, İstanbul, Ege Yayınları, 2003, s. 25-66; Kuban, a.g.e.; Yerasimos, a.g.m.; Hasluck, a.g.e.

25 Bazı çalışmalar için bkz.: Wolfgang Müller-Wiener, İstanbul'un Tarihsel Topografyası: 17. Yüzyıl Başlarına Kadar Byzantion-Konstantinopolis-İstanbul, çev. Ülker Sayın, İstanbul, Yap1 Kredi Yayınları, 2001; Kırımtayıf, Converted Byzantine Churches...; Kırımtayıf, "Fatih Sultan Mehmed ve II. Bayezid...", Tuluk vd., a.g.m.

26 Bu konuda özellikle Murat Sav'ın çalışmaları örnek verilebilir. Bkz.: Murat Sav, "Sancaktar Hayrettin Mescidi", Vakıflar Dergisi, sayı 33, 2010, s. 53-66; Murat Sav, "Mausoleion, Şapel ve Mescid Olarak Balabanağa", Vakıf Restorasyon Yıllı̆̆ , sayı 2, 2011, s. 143-149; Murat Sav, “Tarihsel Süreçte İstanbul/Ayvansaray'daki Toklu İbrahim Dede Mescidi”, Vakıflar Dergisi, sayı 36, 2011, s. 101-120; Murat Sav, "Kazıs1-Projesi-İhya Süreci ve Koruma Prensipleri Açısından İsakapı Mescidi”, Bildiri Kitabı, Tarihi Yapıları Koruma ve Onarım Sempozyumu-TAYKON 2011 (26-29 Ekim 2011, YTÜ, İstanbul), 2011, s. 358-369.

27 Günümüz Türkçesi ile ifadesi: "Sultan'ın zorla fethi meşhurdur, fakat kiliselerin kendi hallerinde bırakılması, barış yoluyla fethine delildir. 944 yılında (153839-) bu durum teftiş edilmiştir. Biri yüz on yedi yaşında bir kişi bulundu, biri de yüz otuz yaşında diğer bir kişi bulundu. Bunlar Yahudilerin ve Hristiyanların gizlice Sultan Mehmed'le ittifak etmesi nedeniyle Bizans tekfurunun zafer kazanamadığına, padişahın onları tutsak etmeyip kendi hallerinde 
Fethedilen beldelerde yeni kilise yapımının neredeyse yasak olduğu bilinmektedir. Kiliselerin camiye çevrilme isteği ise "feth-i Muhammedî"nin tesisi açısından bilinen bir gerçektir. Söz gelimi Ebussud'un yukarıdaki fetvasının yanında "İstanbul'daki bir kilisenin şehrin fethinin hemen ardından mescid olarak kullanılmış olduğuna dair yaşlı tanıkların ifadesinin, bu kilisenin camiye dönüştürülmesini haklı çıkarmaya yeteceğini” belirttiği başka bir fetvası da mevcuttur. ${ }^{28}$ Ayrıca, bir kilisenin Müslüman evlerinin arasında kalmış olması gibi nedenler dönüşümün meşrulaştırılmasının önemli nedenleri arasındadır. 1587-88 tarihinde Teotokos Pammakaristos Manastırı kilisesi, fetihte orada ezan okunmas1 gerekçesiyle, III. Murad'ın Gürcistan zaferinin nişanesi olarak "Fethiye" Camii adıyla camiye çevrilmiştir. ${ }^{29}$ Diğer taraftan, İmparatorluk toprakları genelinde yankı yapan "Fethiye" gibi çevrilmelerin yaygınlaşmasına engel olmak için 1587'de Haleb beylerbeyi ve kadısına gönderilen fermanın kopyaları Şam, Van, Diyarbakır, Trablus, Niğbolu ve Ahyolu'na da gönderilir ve "buralardaki kiliselerin camiye dönüştürülmesini yasaklayarak, her bir şehrin fethi döneminde dokunulmayan kiliselerin Hristiyanların elinde kalmasını emreder". ${ }^{30}$

Bütün bu arşiv kayıtları ve uygulamalardan anlaşıldığına göre, makalenin ilk sayfalarında belirtildiği gibi, kiliselerin camiye dönüştürülme süreçleri her biri için farklı nüansların söz konusu olduğu, tekil konular olarak ayrı çalışılması gerekli meselelerdir.

Fetvalar, fermanlar üzerinden yukarıda anlatılan imparatorluk genelindeki bazı uygulamalar camiye dönüştürülme mantığına ek olarak, nicel bir cevabı olacak soruyu gündeme getirmek ve Osmanlı İstanbul'undaki camiye çevrilme süreçlerine kısaca değinmekle meseleye daha yakından bakılabilir, mesele biraz daha açılabilir: İstanbul için camiye çevrilen kilise sayısı nedir ve süreç nasıl işlemiştir? Bu konuda Yerasimos, "şu anda, bugün Bizans kiliselerinin kaçının camiye

bırakılmasına izin verdiğine ve şehrin bu şekilde fethedildiğine müfettiş huzurunda tanıklık ettiler. Bu tanıklık sayesinde eski kiliseler oldukları halde kalmıştır”. Ebussuud, Fetavâ, TSK, A. 786, varak 128a-b. ve Ertuğrul Düzdağ, Şeyhülislam Ebussuûd Efendi Fetvaları Işı̆̆ında 16. Asır Türk Hayatı, İstanbul, 1972, s. 104'den aktaran Gülru Necipoğlu, Sinan Çağı: Osmanlı İmparatorluğu'nda Mimari Kültür, çev. Gül Çağalalı Güven, İstanbul, İstanbul Bilgi Üniversitesi Yayınlar1, 2015, s. 70.

28 Necipoğlu, a.g.e., s. 71.

29 Klaus Kreiser, "Zur Kulturgeschichte der osmanischen Moschee”, Türkische Kunst aus osmanischer Zeit, Frankfurt am Main, 1985 (1982?), 2 c., 1:75-86'den aktaran Necipoğlu, a.g.e., s. 71.

30 (BOA h.995, s. 65'den aktaran) Başbakanlık Osmanlı Arşivi, Mühimme Defteri 62, nu. 209, s. 95 ve nu. 145, s. 65, tarih: Şevval 995'den aktaran Necipoğlu, a.g.e., s. 72. 
çevrilmiş olduğunu, kaçının kilise olarak hâlâ işlevlerini sürdürdüğünü ve kaçının terkedildiğini ya da yıkıldığını ya da işlevlerinin değiştirildiğini bilemiyoruz, bilmiyoruz" ifadeleriyle bir hüküm ortaya koymaktadır. ${ }^{31}$ Bilememekten kasıt, elbette ki tam ve kesin sayılardır. Bu durumun iki nedeninden birincisi, fetih sırasında İstanbul'da kaç kilisenin olduğunun bilinememesi, ikincisi ise bugün sur içinde yer alan halen kilise işlevli yapılardan sadece birinin Bizans yapısı olmasıdır. Dolayısıyla 16. yüzyıldan bugüne çeşitli saikler (deprem, terkedilme, harap olma, yerine cami yapma vs.) ve Tanzimat'la gelen kilise yapma izniyle kiliselerin y1k1lıp yapılmaları nedeniyle orijinal halde kalamaması tespitleri zorlaştırmaktadır.

Yerasimos'a göre, mimari yapısından ve tarihsel kaynaklardan yola çıkarak bilinebilen camiye çevrilmiş İstanbul Bizans kiliselerinin sayısı yaklaşık 36'dır. Bu "sur içi" yapıların; 5'i Fatih Sultan Mehmet'in hükümdarlık döneminde (1451-1481), 20'si II. Bayezid (1481-1512), 3'ü Kanuni Sultan Süleyman (1520-1566), 2'si III. Murad (1574-1595), 1'si IV. Murad (1623-1640), 1'i İbrahim (1640-1648) dönemlerinde camiye çevrilmiştir. Geriye kalan 4 kilisenin ise camiye çevrilme tarihi tam olarak bilinememektedir. ${ }^{32}$ Eyice'nin iki yayınından derlenen bilgilere göre, sur içinde, toplamda 39 kiliseden çevrilme cami söz konusudur. Bunların 11 tanesi Fatih, 7'si II. Bayezid, 1'i Yavuz (?), 2'si Kanuni, 2'si III. Murad, 2'si IV. Murad döneminde çevrildiği belirtilmektedir. 14 tanesi ile ilgili ise bazı yorumlar yapılmakla birlikte dönem belirtilmemektedir. ${ }^{33}$ Kırımtayıf'ın çalışmasında strüktürü, mimari yapısı korunmuş 19 kilise cami, strüktürü yıkılmış, harabe halde ya da izi kalmamış 20, toplamda ise 39 yapı hakkında bilgiler mevcuttur. Aynı çalışmada 39 yapı şöyle dönemleştirilmektedir: Fatih devrinde 16, II. Bayezid devrinde 10, Yavuz devrinde 1 (?), Kanuni devrinde 2, III. Murad devrinde 2, IV. Murad devrinde 3 ve geriye kalan 5 kilise.$^{34}$ Çelik, Doğan Kuban'a referansla Fatih döneminde 17 kilisenin camiye çevrildiğini, bunun yanında Ömer Lütfi Barkan'a referansla 190 yeni cami yapıldığını yazmaktadır. ${ }^{35}$

Bu sayı ve dönemlendirme farklılıklarından anlaşıldığı kadarıyla sur içi İstanbul'da sayı 40 civarındadır. Çevrilme dönemleriyle ilgili, özellikle bazı küçük yapılarda, farklılıklar görünmektedir. Bu durum doğal karşılanabilir çünkü tartışmalı tarihlendirmelerde çevrilme tarihi/dönemi, eğer kesin bir kayıt söz konusu değilse,

31 Yerasimos, a.g.m., s. 183.

32 Yerasimos, a.g.m., s. 182-184.

33 Eyice, "İstanbul'un Camiye Çevrilen Kiliseleri”; Semavi Eyice, "İstanbul'da Kiliseden Çevrilmiş Cami ve Mescidler ve Bunların Restorasyonu”, Vakıflar Haftası Dergisi, sayı 7, 1990, s. 279-291.

34 Kurımtayıf, Converted Byzantine Churches.

35 Zeynep Çelik, Değişen İstanbul: 19. Yüzyılda Osmanlı Başkenti, çev. S. Deringil, 2. bs., İstanbul, Tarih Vakfi Yurt Yayınları, 1998, s. 22. 
genellikle vakfiye kayıtlarından, vakıf tahrirlerinden, Ayvansarayi'nin Hadikatü'l-Cevami eseri gibi geç dönem eserlerden vb. kaynak gruplarından faydalanılmaktadır. Bütün bu kayıt ve kaynak türleri yapıları gereği "geç" kayıtlar sayılabilir. Söz gelimi, Fatih döneminde yaşamış ricalin vakfını kurması (ya da ardından kurulması) II. Bayezid döneminde olabilmekte, kayıtlarda kiliseden çevirdiği bir cami ile ilgili kesin çevrilme tarihi bulunabilmektedir. Bu durumda kilisenin hangi devirde çevrilmiş olduğu güçlü ya da zayıf olabilecek bir tahminden öteye geçememektedir. Şu kesindir ki, Müller-Wiener' in 29'u hakkında bilgi verdiği, Yerasimos'un yaklaşık 36, Eyice ve Kırımtayıf'ın 39 cami olarak belirttiği sur içi kiliselerin camiye çevrilme süreci en az 200 yıl sürmüştür (Tablo 1, 2, 3). Aşağıda ardarda sıralanan tablolarda kiliseden çevrilen camilerin literatürdeki dönemlendirmeleri, konumları ve durum bilgileri biraraya getirilerek bir bilgi toparlaması yapılmıştır. Ayrıca yerinde gözlemler ve güncel durumları tablolara eklenmiştir.

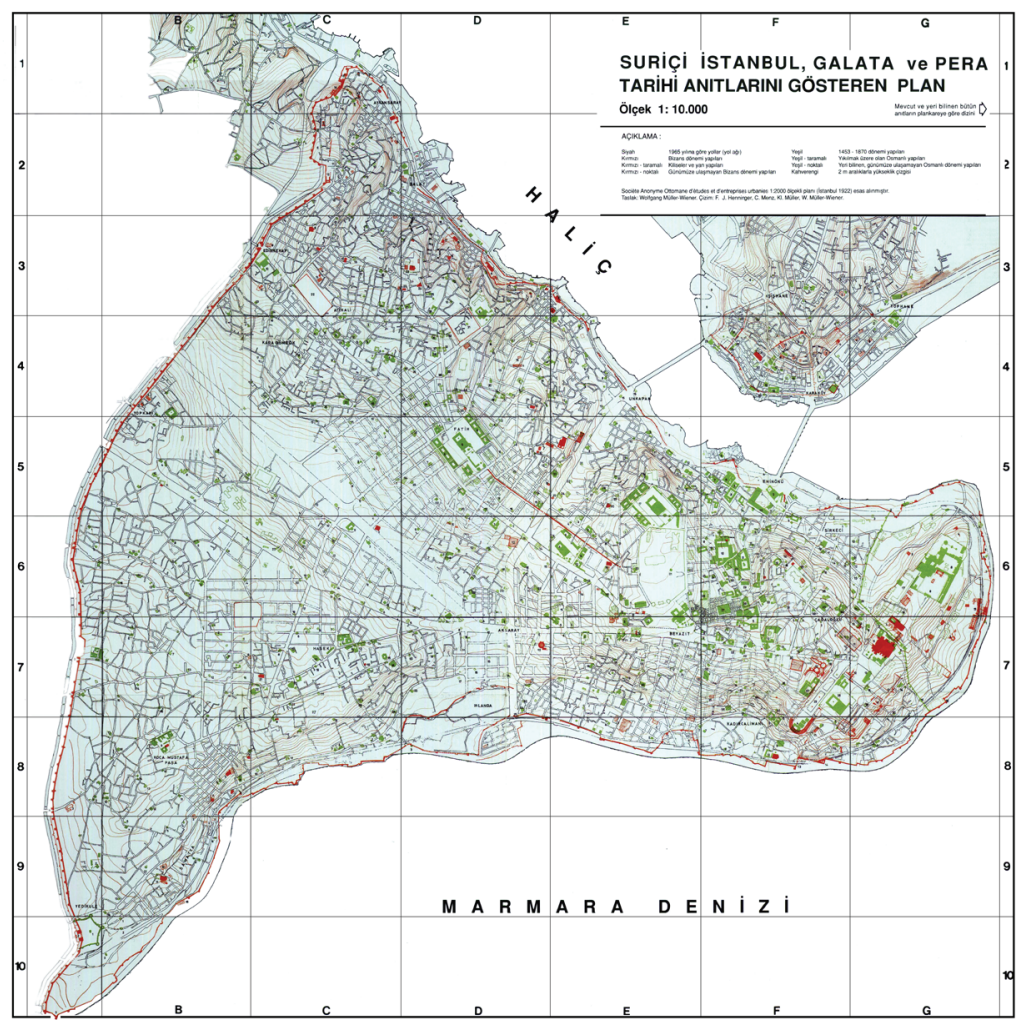

Resim 10. Suriçi İstanbul, Galata ve Pera Tarihi Anıtlarını Gösteren Plan ${ }^{36}$

Müller-Wiener, a.g.e. 

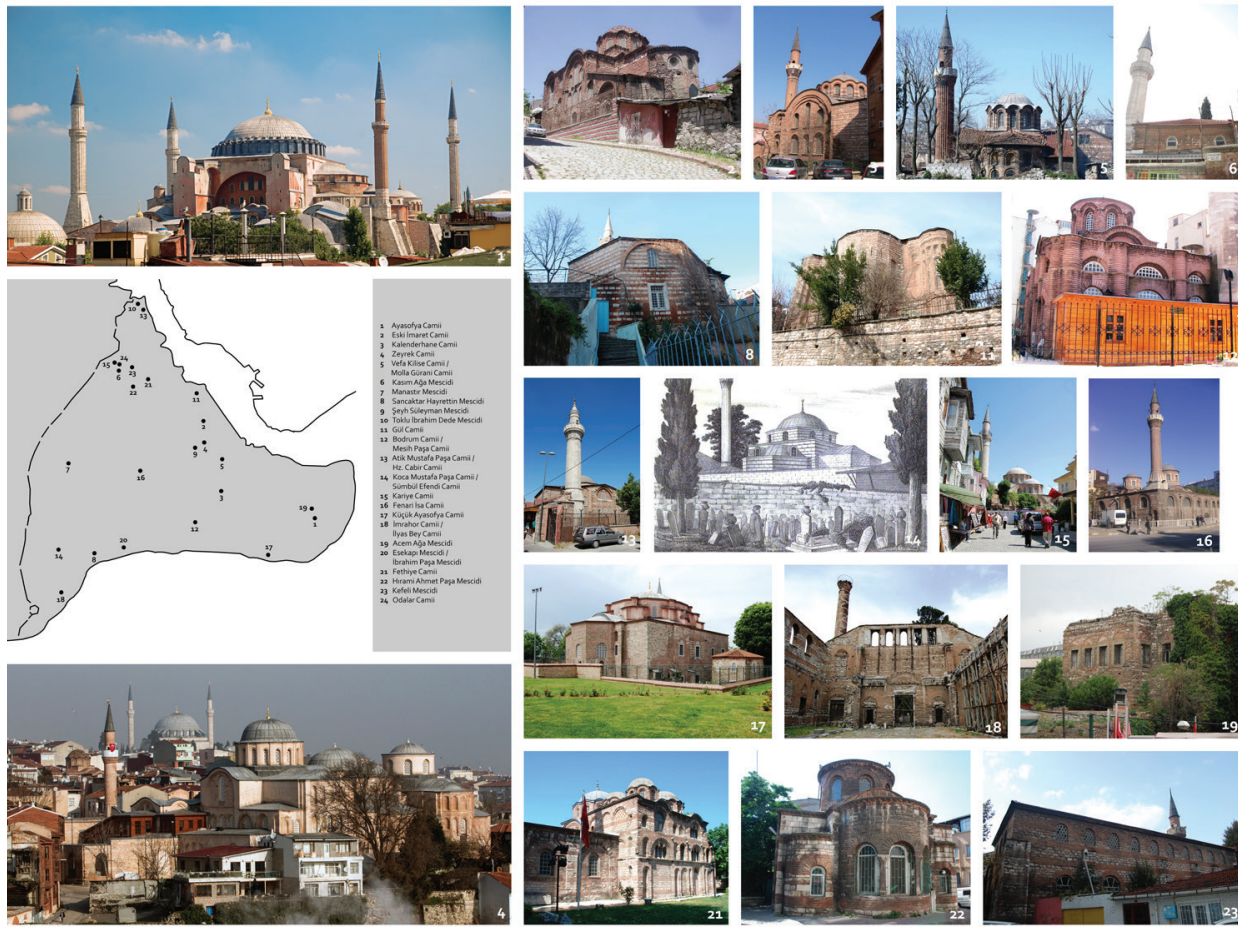

Resim 11. Kiliseden çevrilen suriçi İstanbul cami ve mescidlerinin bazılar ${ }^{37}$

Tablo 1. Kiliseden çevrilen suriçi İstanbul cami ve mescidlerinin konum ve durumları

\begin{tabular}{|c|c|c|c|c|}
\hline & Cami Adı & $\begin{array}{c}\text { Konum } \\
1986 \\
\text { (Semavi Eyice) }\end{array}$ & $\begin{array}{c}\text { Durum } \\
1986 \\
\text { (Semavi Eyice) }\end{array}$ & $\begin{array}{c}\text { Durum } \\
2020\end{array}$ \\
\hline 1 & Ayasofya Camii & Sultanahmet'te & $\begin{array}{l}\text { Faal. } \\
\text { Müze. }\end{array}$ & $\begin{array}{l}\text { Süresiz restorasyon çalışması } \\
\text { devam ediyor. Faal. Cami. }\end{array}$ \\
\hline 2 & Eski İmaret Camii & Fatih'in Haliç tarafinda & Faal. & $\begin{array}{l}\text { Faal. } \\
\text { Kuran kursu. Cami. }\end{array}$ \\
\hline 3 & Kalenderhane Camii & $\begin{array}{l}\text { Şehzadebaşı'nda } \\
\text { Bozdoğan Kemeri yanında }\end{array}$ & $\begin{array}{l}\text { Restore edildi. Faal. } \\
\text { Cami. }\end{array}$ & $\begin{array}{l}\text { Faal. } \\
\text { Cami. }\end{array}$ \\
\hline 4 & Zeyrek Camii & Zeyrek semtinde & $\begin{array}{l}\text { Faal. } \\
\text { Cami. Müze. }\end{array}$ & $\begin{array}{l}\text { Restore edildi. Faal. } \\
\text { Cami. }\end{array}$ \\
\hline 5 & Hoca Hayreddin Mescidi & $\begin{array}{l}\text { Mesih Pașa semti } \\
\text { civarında }\end{array}$ & $\begin{array}{l}\text { Hakkında bir șey bilinmez. } \\
\text { Yeri tam belli degil. }\end{array}$ & $\begin{array}{l}\text { Kayıp eser (Akşemsettin } \\
\text { Mahallesi'nde). }\end{array}$ \\
\hline 6 & Güngörmez Mescidi & - & - & $\begin{array}{l}\text { Kalınt (Sultanahmet'te } 99 \text { ada } \\
\text { 4-5-6 parsel yanı). }\end{array}$ \\
\hline
\end{tabular}

37 Fotoğraflar: (1) Y1lmaz, a.g.e.; (4) Halil İbrahim Düzenli; (2,3,5,6,8,11,12,13,15,15,16,17,18, 19,21,22,23) Murat Sav. 


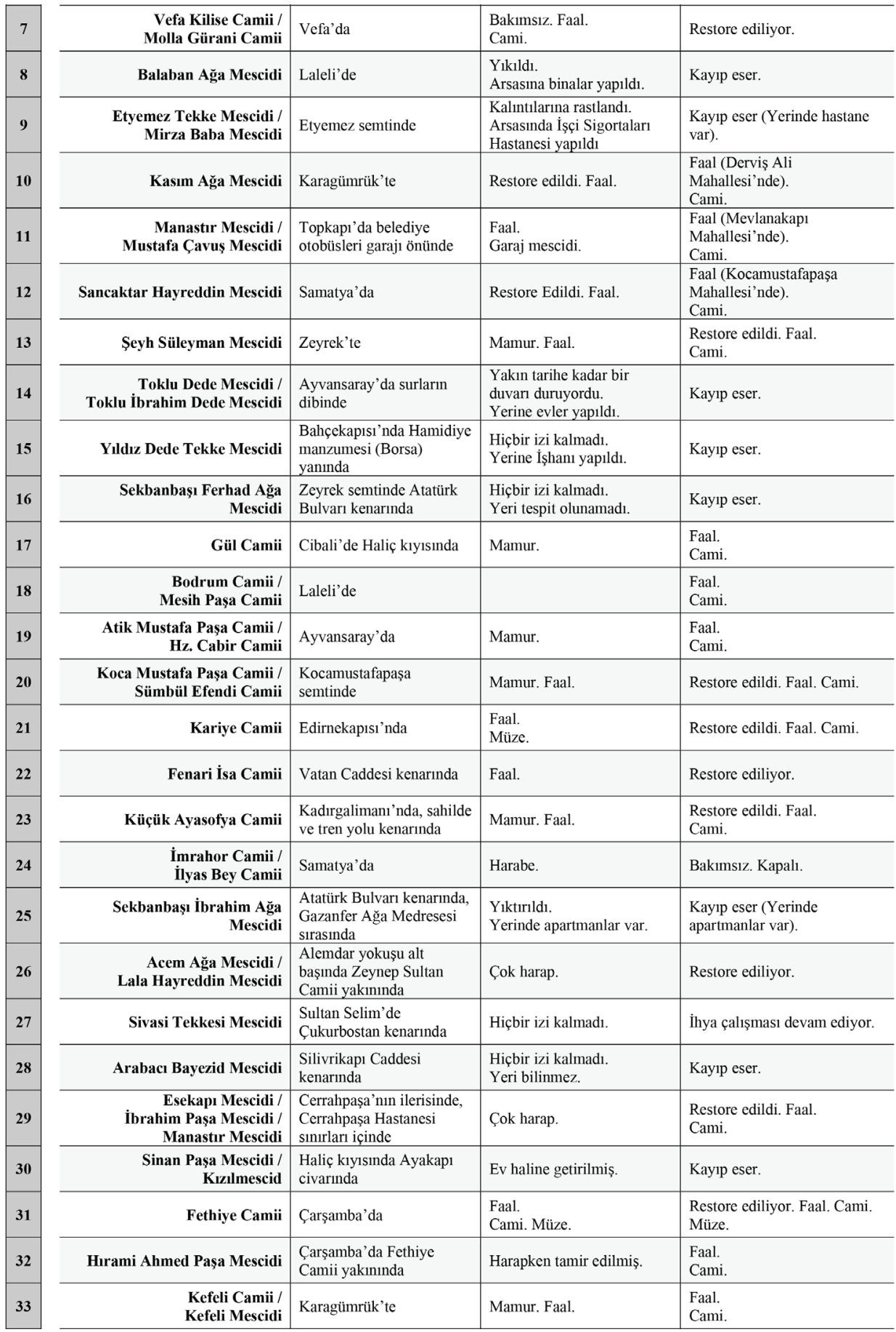




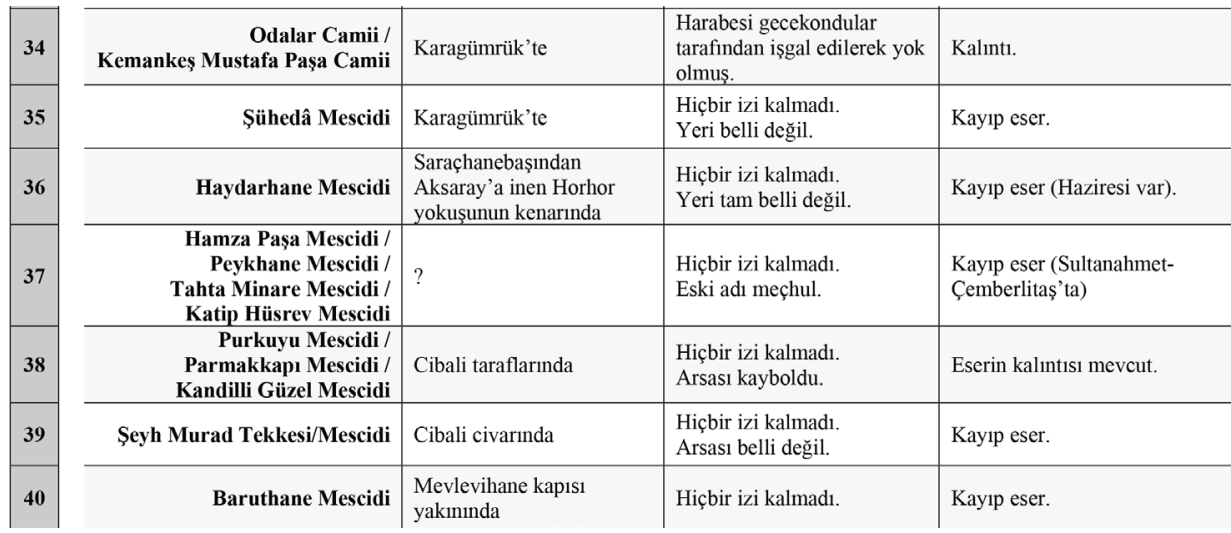

Tablo 2. Kiliseden çevrilen suriçi İstanbul cami ve mescidlerinin dönemlendirmeleri

\begin{tabular}{|c|c|c|c|c|c|}
\hline & Cami Adı & $\begin{array}{c}\text { Dönem } \\
\text { (Eyice 1986) }\end{array}$ & $\begin{array}{c}\text { Dönem } \\
\text { (Eyice 1990) }\end{array}$ & $\begin{array}{c}\text { Dönem } \\
\text { (Kırımtayıf } \\
\text { 2001) } \\
\end{array}$ & $\begin{array}{c}\text { Dönem } \\
\text { (Yerasimos } \\
\text { 2011) } \\
\end{array}$ \\
\hline 1 & Ayasofya Camii & Fatih & Fatih & Fatih & Fatih \\
\hline 2 & Eski İmaret Camii & Fatih & Fatih & Fatih & Fatih \\
\hline 3 & Kalenderhane Camii & Fatih & - & Fatih & Fatih \\
\hline 4 & Zeyrek Camii & Fatih & Fatih & Fatih & Fatih \\
\hline 5 & Hoca Hayreddin Mescidi & $?$ & $\begin{array}{c}\text { ? (HC) } \\
\text { (Hadîkatü'1-Cevâmi'den) }\end{array}$ & $\begin{array}{c}\text { Fatih } \\
\text { 1475-76'dan önce }\end{array}$ & Fatih \\
\hline 6 & Güngörmez Mescidi & - & - & Fatih & - \\
\hline 7 & $\begin{array}{l}\text { Vefa Kilise Camii / } \\
\text { Molla Gürani Camii }\end{array}$ & Fatih & Fetihten az sonra & $\begin{array}{c}\text { Fatih } \\
\text { Molla Gürani } \\
\text { tarafindan }\end{array}$ & II. Bayezid \\
\hline 8 & Balaban Ağa Mescidi & Fatih & - & Fatih & II. Bayezid \\
\hline 9 & $\begin{array}{r}\text { Etyemez Tekke Mescidi / } \\
\text { Mirza Baba Mescidi }\end{array}$ & - & $?(\mathrm{HC})$ & Fatih & - \\
\hline 10 & Kasım Ağa Mescidi & Fatih & $\stackrel{?}{\text { 15. yy minare kalıntısı }}$ & $\begin{array}{c}\text { Fatih } \\
\text { Sekbanbaşı Kasım } \\
\text { Ağa tarafından }\end{array}$ & - \\
\hline 11 & $\begin{array}{r}\text { Manastır Mescidi / } \\
\text { Mustafa Çavuş Mescidi }\end{array}$ & Fatih & $\begin{array}{l}\text { ? } \\
\text { Fethe katılmış Mustafa } \\
\text { Çavuş adına }\end{array}$ & $\begin{array}{c}\text { Fatih } \\
\text { Fatih devrinden } \\
\text { Mustafa Çavuş } \\
\text { tarafindan }\end{array}$ & - \\
\hline 12 & Sancaktar Hayreddin Mescidi & Fatih & $\begin{array}{c}\text { ? } \\
\text { Fethe katılmış Sancaktar } \\
\text { Hayreddin adına }\end{array}$ & Fatih & II. Bayezid \\
\hline 13 & Şeyh Süleyman Mescidi & - & $?$ & $\begin{array}{c}\text { Fatih } \\
\text { Fatih devrinden } \\
\text { Şeyh Süleyman } \\
\text { tarafindan } \\
\end{array}$ & - \\
\hline 14 & $\begin{array}{l}\text { Toklu Dede Mescidi / } \\
\text { Toklu İbrahim Dede Mescidi }\end{array}$ & Fatih & - & Fatih & $\begin{array}{c}\text { II. Bayezid } \\
\text { Bizzat II. Bayezid } \\
\text { tarafindan } \\
\end{array}$ \\
\hline 15 & Yıldız Dede Tekke Mescidi & - & $?(\mathrm{HC})$ & Fatih & - \\
\hline
\end{tabular}




\begin{tabular}{|c|c|c|c|c|c|}
\hline 16 & Sekbanbaşı Ferhad Ağa Mescidi & - & $?(\mathrm{HC})$ & Fatih? & - \\
\hline 17 & Gül Camii & Yavuz? & - & II. Bayezid & $\begin{array}{c}\text { II. Bayezid } \\
\text { Bizzat II. Bayezid } \\
\text { tarafından } \\
\end{array}$ \\
\hline 18 & $\begin{array}{r}\text { Bodrum Camii / } \\
\text { Mesih Paşa Camii }\end{array}$ & II. Bayezid & $\begin{array}{l}\text { II. Bayezid } \\
\text { 15. yy sonlan }\end{array}$ & II. Bayezid & $\begin{array}{c}\text { II. Bayezid } \\
\text { Mesih Paşa } \\
\text { tarafindan }\end{array}$ \\
\hline 19 & $\begin{array}{r}\text { Atik Mustafa Paşa Camii / } \\
\text { Hz. Cabir Camii }\end{array}$ & II. Bayezid & 15. yy sonları & II. Bayezid & $\begin{array}{c}\text { II. Bayezid } \\
\text { Koca Mustafa Paşa } \\
\text { tarafindan }\end{array}$ \\
\hline 20 & $\begin{array}{r}\text { Koca Mustafa Paşa Camii / } \\
\text { Sümbül Efendi Camii }\end{array}$ & II. Bayezid & Fetihten yarım yy sonra & $\begin{array}{l}\text { II. Bayezid } \\
1486\end{array}$ & $\begin{array}{c}\text { II. Bayezid } \\
\text { Koca Mustafa Paşa } \\
\text { tarafindan }\end{array}$ \\
\hline 21 & Kariye Camii & II. Bayezid & $\begin{array}{l}\text { II. Bayezid } \\
\text { 1511'den önce }\end{array}$ & II. Bayezid & $\begin{array}{c}\text { II. Bayezid } \\
\text { Hadım Ali Paşa } \\
\text { tarafından } \\
\end{array}$ \\
\hline 22 & Fenari İsa Camii & II. Bayezid & 15. yy & $\begin{array}{c}\text { II. Bayezid } \\
\text { 1496-97'den önce }\end{array}$ & - \\
\hline 23 & Küçük Ayasofya Camii & II. Bayezid & - & $\begin{array}{c}\text { II. Bayezid } \\
\text { Kapıağas1 Hüseyin } \\
\text { Ağa tarafindan } \\
\end{array}$ & II. Bayezid \\
\hline 24 & $\begin{array}{c}\text { İmrahor Camii / } \\
\text { İyas Bey Camii }\end{array}$ & II. Bayezid & II. Bayezid & $\begin{array}{c}\text { II. Bayezid } \\
\text { İlyas Bey tarafindan }\end{array}$ & II. Bayezid \\
\hline 25 & $\begin{array}{r}\text { Sekbanbaşı İbrahim A Aga } \\
\text { Mescidi }\end{array}$ & Fatih & - & $\begin{array}{c}\text { II. Bayezid ? } \\
\text { 1496-97'den önce }\end{array}$ & II. Bayezid \\
\hline 26 & $\begin{array}{r}\text { Acem Ağa Mescidi / } \\
\text { Lala Hayreddin Mescidi }\end{array}$ & - & $\stackrel{?}{\text { Fetihten sonra }}$ & $\begin{array}{l}\text { II. Bayezid } \\
\text { 1484, Arpa Emini } \\
\text { Lala Hayreddin } \\
\text { tarafindan }\end{array}$ & - \\
\hline 27 & Sivasi Tekkesi Mescidi & $?$ & $?(\mathrm{HC})$ & II. Bayezid & - \\
\hline 28 & Arabacı Bayezid Mescidi & $?$ & $?(\mathrm{HC})$ & Yavuz? & - \\
\hline 29 & $\begin{array}{r}\text { Esekapı Mescidi / } \\
\text { İbrahim Paşa Mescidi / } \\
\text { Manastır Mescidi } \\
\end{array}$ & Kanuni & - & Kanuni & - \\
\hline 30 & $\begin{array}{r}\text { Sinan Paşa Mescidi / } \\
\text { Kızılmescid }\end{array}$ & Kanuni & - & $\begin{array}{c}\text { Kanuni } \\
\text { 1553'den önce }\end{array}$ & - \\
\hline 31 & Fethiye Camii & III. Murad & 16. yy sonu & III. Murad & III. Murad \\
\hline 32 & Hırami Ahmed Paşa Mescidi & III. Murad & 16. yy sonlanı & III. Murad & III. Murad \\
\hline 33 & $\begin{array}{r}\text { Kefeli Camii / } \\
\text { Kefeli Mescidi }\end{array}$ & IV. Murad & IV. Murad & $\begin{array}{c}\text { IV. Murad } \\
\text { 1630'lar }\end{array}$ & $\begin{array}{c}\text { IV. Murad } \\
1626\end{array}$ \\
\hline 34 & $\begin{array}{r}\text { Odalar Camii / } \\
\text { Kemankeş Mustafa Paşa Camii }\end{array}$ & IV. Murad & $\begin{array}{l}\text { IV. Murad ve İbrahim } \\
\text { sadrazamı Kemankeş } \\
\text { Mustafa Paşa tarafindan }\end{array}$ & IV. Murad & $\begin{array}{l}\text { İbrahim } \\
1640\end{array}$ \\
\hline 35 & Şühedâ Mescidi & $?$ & $\begin{array}{c}\text { ?(HC) } \\
\text { IV. Murad Şeyhülislamı, } \\
\text { idam edilen Ahizade } \\
\text { Hüseyin Efendi tarafindan }\end{array}$ & $\begin{array}{l}\text { IV. Murad } \\
\text { 1634'den önce }\end{array}$ & - \\
\hline 36 & Haydarhane Mescidi & $?$ & $?(\mathrm{HC})$ & $\stackrel{?}{\text { 1546'dan önce }}$ & - \\
\hline 37 & $\begin{array}{r}\text { Hamza Paşa Mescidi / } \\
\text { Peykhane Mescidi / } \\
\text { Tahta Minare Mescidi / } \\
\text { Katip Hüsrev Mescidi }\end{array}$ & $?$ & $?(\mathrm{HC})$ & $1682-83 ?$ & - \\
\hline 38 & $\begin{array}{r}\text { Purkuyu Mescidi / } \\
\text { Parmakkapı Mescidi / } \\
\text { Kandilli Güzel Mescidi } \\
\end{array}$ & $?$ & $?(\mathrm{HC})$ & $?$ & - \\
\hline 39 & Şeyh Murad Tekkesi/Mescidi & $?$ & - & $?$ & - \\
\hline 40 & Baruthane Mescidi & $?$ & $?(\mathrm{HC})$ & - & - \\
\hline
\end{tabular}


Tablo 3. Kiliseden çevrilen suriçi İstanbul cami ve mescidlerinin Muller-Wiener tarafından yapılmış dönemlendirmeleri ve ayrıntıları

\begin{tabular}{|c|c|c|c|c|c|c|}
\hline & Cami Adı & $\begin{array}{c}\text { Tarih } \\
\text { (Kilise) }\end{array}$ & Türkçe Adı & Çeviren & $\begin{array}{c}\text { Tarih } \\
\text { (Camiye Çevrilme) }\end{array}$ & $\begin{array}{c}\text { Dönem } \\
\text { (Muller- } \\
\text { Wiener 1977, } \\
\text { 2001) }\end{array}$ \\
\hline 1 & Ayasofya Camii & & $\begin{array}{c}\text { Aya Sofya } \\
\text { Camii; Aya Sofya-i Kebir Cami'-i } \\
\text { șerifi }\end{array}$ & Fatih Sultan Mehmed & 1453 & Fatih \\
\hline 2 & Eski İmaret Camii & $\begin{array}{l}\text { 11. yy'm } 4 . \\
\text { Çeyreği, } 1087 \\
\text { öncesi }\end{array}$ & Eski İmaret Camii, Kilise Camii & Fatih Sultan Mehmed & $\begin{array}{c}1453 \text { sonrasi, } 1463 \text { yılından } \\
\text { itibaren imaret, sonrasında } \\
\text { cami }\end{array}$ & Fatih \\
\hline 3 & Kalenderhane Camii & $\begin{array}{l}\text { 6. yy sonu-12. } \\
\text { yy. }\end{array}$ & $\begin{array}{l}\text { Kalenderhane, Kalenderhane } \\
\text { Camii }\end{array}$ & $\begin{array}{l}\text { Sultan II. Mehmed (1451- } \\
\text { 1481) }\end{array}$ & 15. yy. üçüncü çeyreği & Fatih \\
\hline 4 & Zeyrek Camii & $\begin{array}{l}12 . \text { yy. birinci } \\
\text { yansi (1118- } \\
1124 \text { arasi) }\end{array}$ & $\begin{array}{l}\text { Zeyrek Kilise Camii; Zeyrek } \\
\text { Camii }\end{array}$ & Fatih Sultan Mehmed & 15. yy. ikinci yarısı & Fatih \\
\hline 5 & Hoca Hayreddin Mescidi & & & & & \\
\hline 6 & Güngörmez Mescidi & & & & & \\
\hline 7 & $\begin{array}{r}\text { Vefa Kilise Camii / } \\
\text { Molla Gürani Camii }\end{array}$ & $\begin{array}{l}\text { 10-11. yy } \\
\text { civari }\end{array}$ & $\begin{array}{c}\text { Kilise Camii; Molla Gürani } \\
\text { Camii; Vcfa } \\
\text { Kilise Camii }\end{array}$ & $\begin{array}{l}\text { Şeyhülislam Molla Güranî } \\
\text { Şcmseddin } \\
\text { Ahmed Efendi }(00.1488 / 893 \mathrm{H})\end{array}$ & 15. yy. ikinci yarısı & ? \\
\hline 8 & Balaban Ağa Mescidi & $\begin{array}{l}\text { yak. } 5-6 . \\
\text { yüzyillar }\end{array}$ & Balaban Ağa Mescidi & Balaban Ağa b. Abdullah & $\begin{array}{l}\text { 15. yy ikinci yarısı, } \\
\text { h.888/m. } 1483 \text { 'deki vakıf } \\
\text { belgesinde görülür }\end{array}$ & ? \\
\hline 9 & $\begin{array}{c}\text { Etyemez Tekke Mescidi / } \\
\text { Mirza Baba Mescidi }\end{array}$ & & & & & \\
\hline 10 & Kasım Ağa Mescidi & - & $\begin{array}{l}\text { Kasım Ağa Mescidi; Kasım Bey } \\
\text { Mescidi }\end{array}$ & $\begin{array}{c}\text { Sekbanbaș1 Kasım Bey b. } \\
\text { Abdullah }\end{array}$ & $\begin{array}{c}\text { h.912/m.1506 } \\
\text { Sekbanbași Kasim Bey b. } \\
\text { Abdullah vakfi }\end{array}$ & $?$ \\
\hline 11 & $\begin{array}{r}\text { Manastır Mescidi/ } \\
\text { Mustafa Çavuş Mescidi }\end{array}$ & - & $\begin{array}{l}\text { Manastır Mescidi; Mustafa Çavuş } \\
\text { Mescidi; Kurabalı Mescidi }\end{array}$ & Mustafa Çavuş & 15. yy. ikinci yarısı & Fatih \\
\hline 12 & Sancaktar Hayreddin Mescidi & & & & & \\
\hline 13 & Şeyh Süleyman Mescidi & - & Şeyh Süleyman Mescidi & $\begin{array}{l}\text { Şeyh Süleyman Halife } \\
(0.1491 / 896 \mathrm{H})\end{array}$ & 15. yy. ikinci yarıs & $?$ \\
\hline 14 & $\begin{array}{r}\text { Toklu Dede Mescidi/ } \\
\text { Toklu Ibrahim Dede Mescidi }\end{array}$ & $\begin{array}{c}\text { 11. yy. } \\
\text { ortaları/ikinci } \\
\text { yarısı? }\end{array}$ & Toklu Dede Mescidi & $\begin{array}{c}\text { Ebû Seybetư']-Hudrî̀nin } \\
\text { mezarnda bekçilik yapan Toklu } \\
\text { Ibrahim Dede }\end{array}$ & 15. yy sonu/16.yy bașı & II. Bayezid \\
\hline 15 & Yıldız Dede Tekke Mescidi & & & & & \\
\hline 16 & Sekbanbașı Ferhad Ağa Mescidi & & & & & \\
\hline 17 & Gül Camii & $\begin{array}{c}11 . \text { yy } \\
\text { sonu'12. yy } \\
\text { birinci yarısı } \\
\end{array}$ & Gül Camii & $\begin{array}{c}\text { Şeyhülislam Molla Hüsrev } \\
\text { Mehmed Efendi'nin (ö.1480/885 } \\
\text { H) vakff ? }\end{array}$ & $\begin{array}{c}\text { 15. yy ikinci yarısı, } \\
1490(895 \mathrm{H}) \text { yılında vakıf } \\
\text { belgelerinde görülür }\end{array}$ & ? \\
\hline 18 & $\begin{array}{r}\text { Bodrum Camii / } \\
\text { Mesih Paşa Camii }\end{array}$ & $\begin{array}{l}\text { 10. yy başı, } \\
922 \text { 'den önce }\end{array}$ & Bodrum Camii, Mesih Paşa Camii & $\begin{array}{c}\text { Sadrazam Mesih Ali Paşa } \\
(0.1501 / 907 \mathrm{H})\end{array}$ & 15. yy sonları, 1501 'den önce & II. Bayerid \\
\hline 19 & $\begin{array}{r}\text { Atik Mustafa Paşa Camii / } \\
\text { Hz. Cabir Camii }\end{array}$ & $\begin{array}{c}\text { yak., } 11 .-12 \\
\text { yüzyıl }\end{array}$ & $\begin{array}{l}\text { Koca Mustafa Paşa Camii; } \\
\text { Hazreti Cabir Camii }\end{array}$ & $\begin{array}{l}\text { II. Bayezid'in bassveciri Koca } \\
\text { Mustafa Paşa (o. 1512) }\end{array}$ & $\begin{array}{l}\text { 16. yy başı, } \\
\text { 1512'den önce }\end{array}$ & II. Bayezid \\
\hline 20 & $\begin{array}{l}\text { Koca Mustafa Paşa Camii / } \\
\text { Sümbül Efendi Camii }\end{array}$ & $?$ & $\begin{array}{l}\text { Koca Mustafa Paşa Camii; Sünbüil } \\
\text { Efendi Camii; Kızlar Kenisesi }\end{array}$ & $\begin{array}{c}\text { Önce Kapıcıbassı ve sonraki } \\
\text { Büyük vezir Koca Mustafa Paşa } \\
(\delta .1512 / 918 \mathrm{H})\end{array}$ & $\begin{array}{c}\text { 15. yy sonu, } \\
\text { 1486-1491/891-896H }\end{array}$ & II. Bayezid \\
\hline 21 & Kariye Camii & $?$ & $\begin{array}{l}\text { Kariye Camii; Ali Pașa Kenise } \\
\text { Camii }\end{array}$ & $\begin{array}{l}\text { II. Bayezid'in büyük veziri Hadım } \\
\text { (Atik) Ali Paşa (ö. 1511/917H) }\end{array}$ & 16. yy. bașı & II. Bayezid \\
\hline 22 & Fenari İsa Camii & 907 & $\begin{array}{c}\text { Fenari İsa } \\
\text { Camii; Kilise Camii }\end{array}$ & $\begin{array}{c}\text { Molla Şemseddin Fenari’nin } \\
\text { yeğeni Rumeli kazaskeri Alaeddin } \\
\text { Ali b. Yusuf Fenari'nin (ö. 1497-8 } \\
\text { ( } 903 \text { H) vakfi }\end{array}$ & 15. yy sonu, yak. 1460-1480 & ? \\
\hline 23 & Küçük Ayasofya Camii & $\begin{array}{l}\text { 6. yy birinci } \\
\text { yarısı }\end{array}$ & $\begin{array}{c}\text { Küçük Ayasofya Camii; Hüseyin } \\
\text { Ağa Camii }\end{array}$ & $\begin{array}{c}\text { Sultan II. Bayezid'in Babüssaade } \\
\text { Ağası Küçük Hüseyin Ağa b. } \\
\text { Abdülhay } \\
\text { (o. yak. 1510) }\end{array}$ & $\begin{array}{c}\text { 16. yy başlangıcı, } \\
\text { arası }\end{array}$ & II. Bayezid \\
\hline 24 & \begin{tabular}{r|} 
İmrahor Camii/ \\
İlyas Bey Camii
\end{tabular} & 463 & $\begin{array}{c}\text { İmrahor } \\
\text { Camii; Emir Ahır Camii, Emir } \\
\text { Ahûr Camii }\end{array}$ & $\begin{array}{l}\text { Sultan II. Bayezid'in imrahoru } \\
\text { illyas Bey b. Abdullah }\end{array}$ & 15. yy sonu/16. yy başlangıcı & II. Bayezid \\
\hline 25 & $\begin{array}{r}\text { Sekbanbaşı İbrahim Ağa } \\
\text { Mescidi }\end{array}$ & $\begin{array}{c}\text { yak. 11-12. } \\
\text { yy'lar }\end{array}$ & Sekbanbașı İbrahim Ağa Mescidi & $\begin{array}{l}\text { Sekbanbașt Ibrahim Ağa } \\
(0.1496 / 902 \mathrm{H})\end{array}$ & 15. yy sonu & \\
\hline 26 & $\begin{array}{r}\text { Acem Ağa Mescidi/ } \\
\text { Lala Hayreddin Mescidi }\end{array}$ & $\begin{array}{l}\text { Pulkheria } \\
\text { (399-453) } \\
\text { tarafindan }\end{array}$ & $\begin{array}{c}\text { Acem Ağa } \\
\text { Mescidi: Hayreddin Ağa Mescidi; } \\
\text { Lala Hayreddin } \\
\text { Mescidi } \\
\end{array}$ & Arpa Emini Lala Hayreddin & h.889/m.1484 & II. Bayezid \\
\hline 27 & Sivasi Tekkesi Mescidi & & & & & \\
\hline 28 & Arabacu Bayezid Mescidi & & & & & \\
\hline 29 & $\begin{array}{r}\text { Esekapı Mescidi / } \\
\text { İbrahim Paşa Meseidi/ } \\
\text { Manastır Mescidi }\end{array}$ & $\begin{array}{l}\text { 13. yy } \\
\text { sonu/14. yy }\end{array}$ & $\begin{array}{c}\text { Esekapı Mescidi; } \\
\text { İsakapı Mescidi; Manastır } \\
\text { Mescidi; daha seyrek } \\
\text { olarak: İbrahim Paşa Mescidi. }\end{array}$ & Hadım İbrahim Paşa (ö. 1562/3) & $1551-1560$ arası & Kanuni \\
\hline 30 & $\begin{array}{r}\text { Sinan Paşa Mescidi / } \\
\text { Krzılmescid }\end{array}$ & $\begin{array}{l}\text { 14. yy birinci } \\
\text { yarıst? }\end{array}$ & $\begin{array}{l}\text { Sinan Paşa Mescidi; } \\
\text { Kızll Mescid }\end{array}$ & 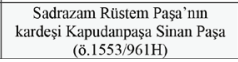 & 16. yy. ortası & Kanuni \\
\hline
\end{tabular}




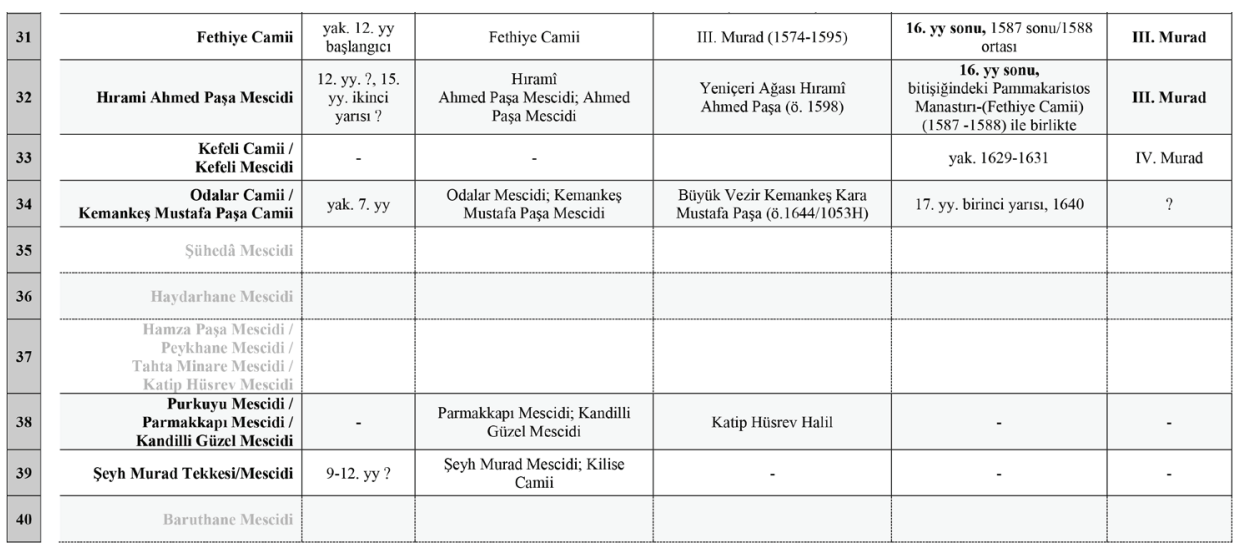

1472-73 yılında inşası bitirilen Fatih Camii'ni müteakiben yapılan Fatih Vakfiyesi’nde Ayasofya'dan başka suriçi ve dışında olmak üzere beş kilisenin daha camiye çevrildiğinden bahsedilmektedir. 1583 ve 1604 tarihli olarak hazırlanabilen listelere göre, kilise olarak varlığını devam ettiren yapı sayısı 34 olarak ifade edilmektedir. 17. yüzyıl başı itibarıyla üzerinde konuşulan kilise sayısı toplamda 70 civarındadır. $^{38}$

Camiye çevrilen kilise sayılarını adlarını yukarıdaki gibi özetledikten sonra, bu altlık üzerine, çevrilme dönemleri ve süreçleriyle ilgili yorumlamalarda bulunulabilir. Fatih dönemi ile diğer padişahların dönemleri ve dahi her kilisenin dönüştürülme süreçleri farklı parametreler etkisinde gerçekleşmiştir.

Fatih döneminde Zeyrek Cami'nden çok daha büyük ve görünür camiler sultan ve paşalar tarafından inşa edilmişti. Temel tercihin bu yönde olduğu söylenebilir. Söz gelimi Fatih Camii, Mahmud Paşa Camii, Has Murad Paşa Camii bu eserler arasındadır. Şehre İslam mührünün Ayasofya'dan sonra en önemli görüntüleri kuşkusuz yeni inşa edilen camilerdi. Bu bağlamda, Zeyrek de dahil olmak üzere kiliselerin camiye çevrilmelerinin daha farklı, karmaşık ve de tabii süreçlerin sonucu olduğunu söylemek yanlış olmasa gerek. Yerasimos konuyu şöyle özetmektedir:

"Fatih döneminde az sayıda kilisenin camiye çevrilmiş olmasının nedeni, bu binalara kilise olarak duyulan ilgiden çok, yapı olarak duyulan ilgisizliktir. Yani en önemli ve görkemli kilise Ayasofya ile bir bakıma önemli gözüken Zeyrek camiye çevrilmiştir. Bunun yanı sıra geri kalan kiliselerden daha büyük olan camiler yapılmıştır. Bu kiliselerin en büyü- 
ğü olabilecek Aziz Sergios ve Bakhhos, Mirelaion ya da Lips Manast1rı’nı göz önüne alırsak, Mahmud Paşa Camii, Has Murad Paşa Camii en azından hacim olarak daha büyük, daha görkemli ve daha anıtsal binalardır. Bu önemli kişiler görkemli camileri için yeni binalar yaptırmayı tercih etmiştir. Aynı zamanda, iskânın hâlâ yoğun olmamasından dolayı camiye çevrilecek binalara olan talebin az olduğu da bir varsayım olarak düşünülebilir". 39

Ayasofya dışında Fatih'in vakfiyesinde, suriçinde kayıtlı olan üç kilise daha bulunmaktadır. Bunlar Eski İmaret Camii, Kalenderhane Cami ve Zeyrek Cami'dir. Bu üç yapının ilk işlevleri ise, mescid hüviyetinde bir mekanı barındırmalarının yanında, doğrudan cami değildir. Başlangıçta, Eski İmaret, adından da anlaşılacağı gibi bir imaret, Kalenderhane, Kalenderi dervişleri için tekke, Zeyrek ise Molla Zeyrek' in müderrisi olduğu medrese işlevini görmüştür. Bu durumu dönem kayıtlarında örneklemek gerekirse, Fatih'in vakfiyesinde Eski İmaret için şunlar yazılıdır: "Eski İmaret odaları demekle mâruftur, sâbıka kenîse, hâlâ Eski İmaret demekle mâruf mescide mülâsıktır" ${ }^{40}$ Fatih döneminde kiliselerin camiye çevrilme konusundaki "ilgisizlik" hakkında Eyice de benzer görüşleri paylaşmaktadır:

"Bizans kiliselerinden bunların dışında yalnız bir tanesi daha Fatih devrinde mescid haline getirilmiştir: bu da Sultan II. Mehmed'in hocası Molla Gürani vakfından camiye çevrilen Vefa semtindeki kilisedir ki, eski adı bilinmemekle beraber Hagios Theodoros Tyron kilisesi olduğu zannedilir. Fatih devrinde bunun dişında İslam ibadetine tahsis kılınan yapılar, eski adları meçhul bazı ufak şapeller ve bazı kiliselerin harap kalıntılarıdır. İşte Manastır mescidi (Mustafa Çavuş); Balaban Ağa, Sancaktar Hayreddin Ağa, Sekbanbaşı İbrahim Ağa, Toklu İbrahim Dede, Kasım Ağa mescidleri gibi küçük binalar bizans menşeli oldukları muhakkak birtakım eserlerdir. Bunlar fethin hemen arkasından mescid haline getirilmiş olmakla beraber Türk bânileri ya az tanınmış veya tamamen meçhul kimselerdir veya fethin şehidleri hatırasına ‘teberrüken' vakf edilmişlerdir."41

39 Yerasimos, a.g.m., s. 190.

40 Semavi Eyice, "Eski İmaret Camii", İslam Ansiklopedisi, cilt 11, İstanbul, Türkiye Diyanet Vakfi Yayınları, 1995, s. 391.

41 Eyice, "İstanbul'un Camiye Çevrilen Kiliseleri”, s. 10; Semavi Eyice, “İstanbul'un Fethinde Bizans Mimarisi”, Eyüpsultan Sempozyumu VII, İstanbul, Eyüp Belediyesi Kültür ve Turizm Müdürlüğü Yayınları, 2003, s. 40. 
Fatih dönemindeki yeni cami yapımına ağırlık verilip eski kiliselere dokunmama yönündeki bu tavır "ilgisizlikle" açıklanacağı gibi, Necipoğlu'nun şu değerlendirmeleriyle de ilişkilendirilebilir:

"II. Mehmed'in, İstanbul'un I. Konstantin ve I. Iustinianus gibi en muhteşem imparatorlarının 'altın çağındaki' kadim ihtişamını canlandırma özlemi, aşağı yukarı, V. Nikola (1447-55) ile IV. Sixtus'un (147184) papalıkları arasında Roma'daki Antikite mirasının yenilenme akımıyla örtüşen, iyi belgelenmiş bir projedir. Osmanlıların vasalı olarak adeta bir şehir-devleti hükümdarına dönüşerek, eski prestijini kaybeden Konstantinopolis 'Tekfur'unu ortadan kaldıran II. Mehmed'in emeli, geç dönem Bizans'ındansa, Doğu Roma İmparatorluğu'nun görkemini payitahtında yeniden sahnelemekti. Dolayısıyla bu, bir kültürel devamlılık olgusu değil, yitirilen prestijli bir geçmişi eski gücüne kavuşturmak vizyonuydu. Kritovoulos'un padişaha sunduğu Rumca kronikte (Historia, y. 1467) belirttiğine göre, Batı'yı Doğu'yla, Mesih Paşa ise Mirelaion Kilisesi'ni Bodrum Camii adıyla bilinen camiye çevirmiştir. Vezir Murad Paşa 1473'de Aksaray'da son derece görkemli camisini yaptırırken, başvezir Mesih Paşa çok daha küçük bir kiliseyi camiye çevirmiştir.42 Diğer devlet ricalinden Kapıağası Hüseyin Ağa tarafında çevrilen Küçük Ayasofya Camii (Aziz Sergius ve Bacchus Kilisesi) ve Mirahur İlyas Bey tarafından çevrilen İmrahor İlyas Bey Camii (Studios Manastırı Kilisesi) dönemin diğer iki önemli yapısıdır.

II. Bayezid devrinde Osmanlı'ya miras kalan manastır kiliseleri içinde yer alan ve camiye çevrilen Fenari İsa Cami'nin içinde barındırdığı yaşanmışlıklar, mimari ekler, başka bir deyişle tekil öyküsü kayda değerdir. Camiye dönüştürülen her kilise aslında bu anlamda dikkate değerdir ve titiz, derinlikli çalışmalara ihtiyaç duyulmaktadır. Meryem Ana (Theotokos) Konstantinos Lips Manastırı Kilisesi adıyla bilinen yapı, II. Andronikos döneminde Bizans İstanbul'unun faal olan yaklaşık kırk manastırından bir tanesidir. Yap1 907 veya 908 yılında İmparator IV. Leo'nun katılımıyla gerçekleşen bir ayinle açılmıştır. İstanbul'un meşhur Latin İstilası döneminden nasibini alan yap1, VIII. Mikhael Palaiologos'un (1223- 1282) karıs1 ve II. Andronikos'un (1282-1328) annesi Theodora Palaiologina himayesinde önemli bir tamirat görmüştür. Theodora Palaiologina, yap1nın Palaiologoslar için bir mezar kilisesi olmasını arzu etmiştir. Osmanlı dönemi öyküsü hakkında bilinenler ise şunlardır: 
"Yapının hangi dönemde kiliseden camiye çevrildiği konusunda kesin bir bilgi yoktur. Kimi görüşlere göre bu düzenleme Fatih Sultan Mehmet (1451-1481) döneminde 1460-1480 arası bir dönemde yapılmıştır. Bir diğer görüş ise II. Bayezid (1481-1512) arasındaki bir dönemde bunun gerçekleştiğini iddia etmektedir. Ancak 1929 yılı civarında yapıdaki kazıyı yürüten Th. Macridy’nin incelemelerine göre bu dönüştürme sadece Theodora tarafından eklenen Güney Kilise’de gerçekleştirilmiş, Kuzey’deki XI. Yüzyıla tarihlenen ilk kilise ise bir tekke olarak düzenlenmiştir. Bu görüşü güney kiliseye eklenen ancak kuzeydekinde bulunmayan, mihrap, minber gibi eklemeler desteklemektedir. Ayrıca 1498 yılında Rumeli Kazaskeri Fenerizade Alaeddin Ali tarafından güney kilisenin güneydoğu duvarına bir minare de eklenmiştir. 1636 yılında dönemin sadrazamlarından Bayram Paşa tarafından köklü bir onarım gördüğü vakıf defterlerinden anlaşılmaktadır. Bu tadilat sırasında güney kiliseye yeni bir minber inşa edilerek kuzey kilise de tekke olarak düzenlenmiştir. Yapının mescid olduğu dönemde imamı olarak görev yapan İsa el Mahvi manastırdan geriye kalabilmiş hücreleri Halveti zaviyesine dönüştürmüştür. Yapı bu tarihe dek kayıtlarda manastır mahallesindeki cami olarak geçmekteyken bu tarihten itibaren dönüşümü gerçekleştiren iki kişinin adlarının birleşimi olan Fenari İsa adıyla anılmaya başlanmıştır". ${ }^{43}$

Camiye dönüştürülen "manastır mahallesindeki cami”, Bizans şehrinin Osmanlı şehrine dönüşümüne, Osmanlı'nın kendi içindeki dönüşümlerine ismi ve hikayesi bağlamında önemli bir tanıktır. Mimari bir eser olarak kilise/caminin öyküsü, bünyesinde İmparator VI. Leo (Konstantinos Lips, m. 886-912), VIII. Mikhael Palaiologos (m. 1223- 1282), II. Andronikos (m. 1282-1328), İmparatoriçe Theodora Palaiologina ile Fatih Sultan Mehmed (m. 1451-1481) ya da II. Bayezid (m. 1481-1512), Rumeli Kazaskeri Fenarizâde Alaeddin Ali, İmam İsa el-Mahvi, Sadrazam Bayram Paşa gibi kişilikleri barındırmaktadır. Biri kazasker ve diğeri imam iki kişinin isimlerinden mülhem olarak Fenari İsa Camii adıyla bilinen yap1, Bizans'1n ve de Osmanlı'nın İstanbul'a miras bıraktıkları, günümüze ulaşabilmiş küçük bir tezyin unsurudur. Bu anlamda, mimari eser aracılı̆̆1 ile yöneticilerin, kişilerin, inancın, gündelik yaşamın ve tabi ki inşa faaliyetinin küçük ama manidar bir kesitidir.

43 Esra Güzel Erdoğan, "Meryem Ana (Theotokos) Konstantinos Lips Manastırı Kilisesi (Fenari İsa Camii)", Antik Çă̆’dan XXI. Yüzyıla Büyük İstanbul Tarihi, bölüm ed. Halil İbrahim Düzenli, genel ed. Coşkun Yılmaz, cilt 8 (mimari), İstanbul, İSAM ve İBB Kültür A.Ş. Yayınları, 2015, s. 59. 
Yukarıda ifade edilenlere ek olarak, II. Bayezid devri vaktiyle Fatih'in el koyduğu ve tımar toprağı haline getirdiği mülkleri sahiplerine iade etme" bakımından "Bilhassa tekke şeyhlerinin bu anlamda arazilerini geri aldıkları, başvuranların hemen hepsinin isteklerinin karşılanmış olduğu" bir dönemdir. ${ }^{44}$ Aynı dönemde camiye çevrilen kilise sayısı noktasındaki "fazlalık" çeşitli grupların küçük ve harap kiliseleri camiye çevirmiş olabileceğini akla getirmektedir. II. Bayezid dönemi hakkında, farklı disiplinlerden dönem araştırmaları çoğaldıkça kiliseden camiye çevrilme motivasyonu daha iyi anlaş1labilecektir.

Bayezid döneminden sonra camiye çevrilen kilise sayısı son derece azdır. En önemlileri arasında Kanuni devrinde çevrilen Esekapı Mescidi ve II. Murad döneminde çevrilen ve çevrilme öyküsü yukarıda anlatılan Fethiye Cami (Pammakaristos Kilisesi) bulunmaktadır. Hırami Ahmed Paşa Mescidi de bu dönemde çevrilmiştir. IV. Murad devrinde 1626'da çevrilen Kefeli Camii (Manuel Manastırı) ve Kemankeş Mustafa Paşa tarafından 1640'da çevrilen Odalar Camii ile kiliselerin camiye çevrilme dönemi son bulmuştur denebilir.

44 Feridun Emecen, Imparatorluk Çağının Osmanlı Sultanları I: Bayezid (II), Yavuz, Kanûnî, 3. bs., İstanbul, İSAM Yayınları, 2014, s. 25. 

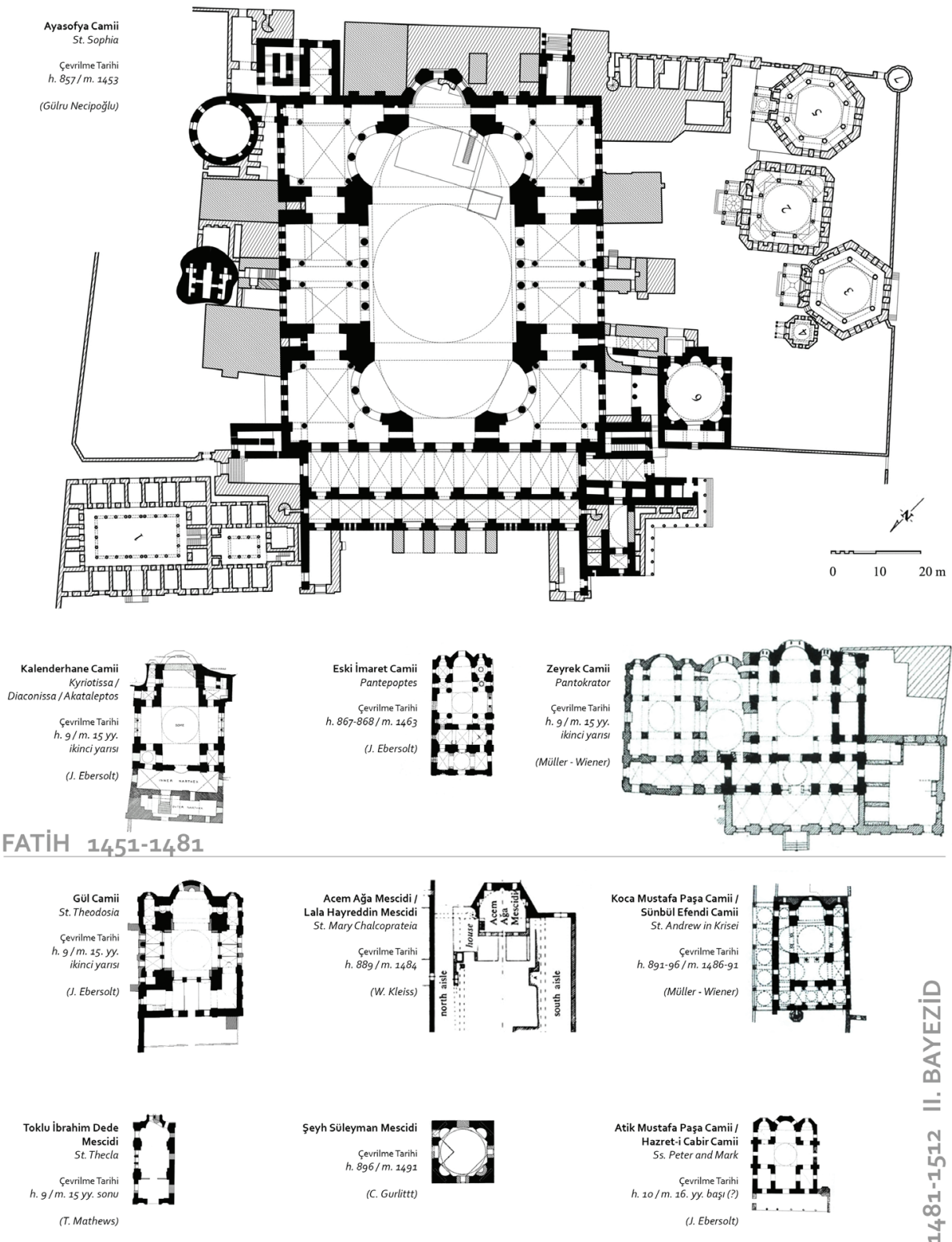

Resim 12. Kiliseden çevrilen suriçi İstanbul cami ve mescidlerinin eş ölçekli planları-1 

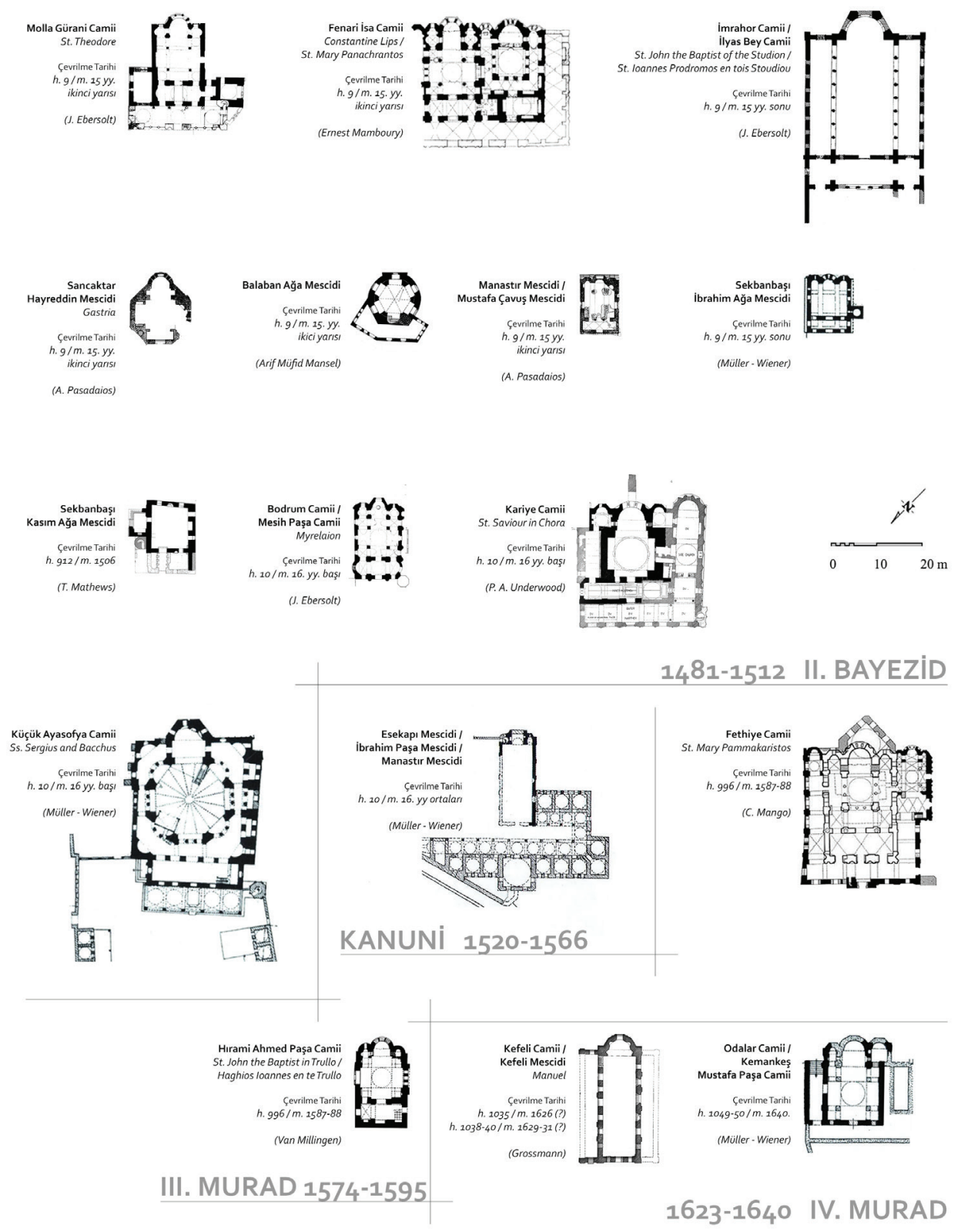

Resim 13. Kiliseden çevrilen suriçi İstanbul cami ve mescidlerinin eş ölçekli planları-2 


\section{Bir Dönüşüm Örneği Üzerine Yorumlar:}

\section{Zeyrekbaşı Püştesi/Seddi/Yokuşu ve Zeyrek Camii}

Zeyrek semti, Bizans devrinden Osmanlı devrine ve de Cumhuriyet'e her dönem önemli bir meskun mahal olarak gözükmektedir. Bugünkü (2016) idari sınırlarda Fatih ilçesi sınırlarında kalan Zeyrek Dünya Miras Alanı Zeyrek Mahallesi ve Cibali Mahallesi'nin bir kısmını içine almaktadır. Zeyrek Dünya Miras Alanı yerleşiminin en önemli özelliği Bizans döneminden bugüne kadar yapılmış çeşitli teras ve setlerle şekillenmiş oluşudur. Atatürk Bulvar1 ve Haliç kotlarından istinat duvarları ve teraslamalar yoluyla yerleşime uygun düzenlemeler yapılmıştır. "Zeyrek püştesi" (yükseltisi, tepeciği) ya da "Zeyrek seddi" semtin bu ana karakterinin Osmanlı metinlerine yansımış ifadesidir.

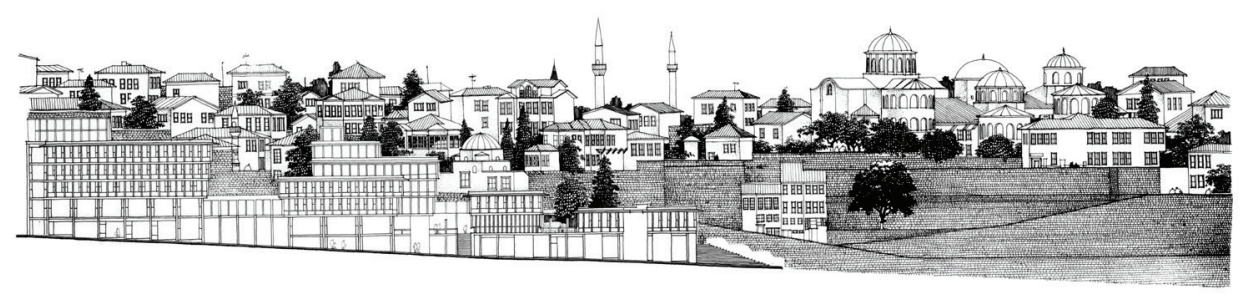

Resim 14. Zeyrek seddini gösteren siluet (Çizim: Sedad Hakkı Eldem)

Semtin en önemli mimari eseri, Fatih Sultan Mehmet'in hükümdarlık döneminde camiye ve medreseye çevrilen Pantokrator Kilisesi'dir. Manastır'ın ilk kilisesi olan Pantokrator İsa Kilisesi'nin yapımı 12. yüzyıla tarihlenmektedir. Bu kilise güney kilisesi olarak bilinir. Ondan sonra bu yapının kuzeyine “Şefkatli Meryem”e sunulmuş bir kilise daha yapılmıştır. Manastır kompleksinin üçüncü yapı ise iki kilisenin arasına Baş Melek Mikail adına yapılmış iki kubbeli mezar şapelidir. II. İoannes Komnenos (ö. 1143) buraya gömülmüştür. Ayrıca manastırın bugüne ulaşmamış yapıları olduğu söylenmektedir. Orta Bizans devrinin bir hastanesi ve yardım merkezi olarak vakfiye kayıtları bulunmaktadır. ${ }^{45}$ İstanbul'un fethinden sonra, Fatih Külliyesi'nin medresele-

45 Michel Kaplan, "Büyük Bir İmparatorluk Vakfi: Pantokrator (Zeyrek Cami)”, Bizans: Yapılar, Meydanlar, Yaşamlar, ed. Annie Pralong, çev. Buket Kitapçı Bayrı, İstanbul, Kitap Yayınevi, 2011, s. 118-134. 
ri yapılıncaya kadar medrese olarak kullanılmış, medrese ve müderrisi Molla Zeyrek Efendi Fatih medreselerine taşındıktan sonra ise cami olarak işlevine devam etmiştir. Medresenin müderrisi Molla Zeyrek Mehmet Efendi'dir. Mahallenin ismi, Fatih vakfiyelerinde Molla Zeyrek'ten mülhem "Molla Zeyrek Mahallesi" olarak geçmektedir: "Biri dahi yine mahmiye-i Konstantiniyye'de ulemâ-yı kirâmdan Mevlâna Zeyrek sâkin olmak ile, Molla Zeyrek Mahallesi dedikleri mahallede vâki kenîsedir ki inşallah Zeyrek Camii ismi ile müsemma olmak mervîdir". ${ }^{46}$

Bölgenin etnik çeşitliliği 16. yüzyıl sonlarına kadar sürmüş, bu tarihten itibaren yoğun bir Müslüman nüfusa ev sahipliği yapmıştır. Semt sakinlerinin genellikle Hanlar bölgesinde çalışmakta olan toplum kesimleri olduğu öne sürülmektedir. ${ }^{47} \mathrm{Bu}$ Müslüman sınıfların konutlarına ek olarak bölgede Osmanlı'nın ileri gelenlerinin konakları olduğu da bilinmektedir. Eğime paralel ve dik yollar semtin konut dokusunu belirlemiştir. Dokunun bir diğer temel karakteristiğini, büyük çoğunluğu 1880-1940 yılları arasında yapılmış, alanda halen varlığını devam ettiren sıra evler, konutlar oluşturmaktadır. Bu konutlar taban alanı yaklaş1k 50 metrekare olan 2 ve 3 katlı konutlardır. Sokağa bakan cephelerde farklı yükseklik ve genişliklerde cumbalar bulunmaktadır. Parsellerin arka tarafları ise küçük bahçelerdir. ${ }^{48}$
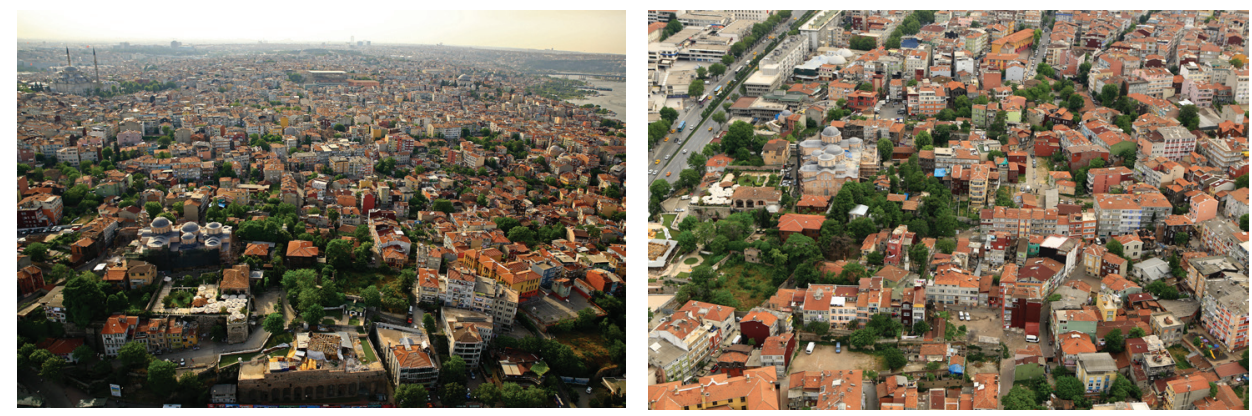

Resim 15-16. Zeyrek semti (F.: İhsan İlze)

46 Semavi Eyice, “Zeyrek Kilise Camii”, Dünden Bugüne İstanbul Ansiklopedisi, cilt 7, İstanbul, Tarih Vakfi Yurt Yayınları, 2003, s. 555.

47 Aykut Karaman - Şebnem Önal, “Zeyrek”, Dünden Bugüne İstanbul Ansiklopedisi, cilt 7, İstanbul, Tarih Vakfı Yurt Yayınları, 1994, s. 553.

Karaman vd., a.g.m. 


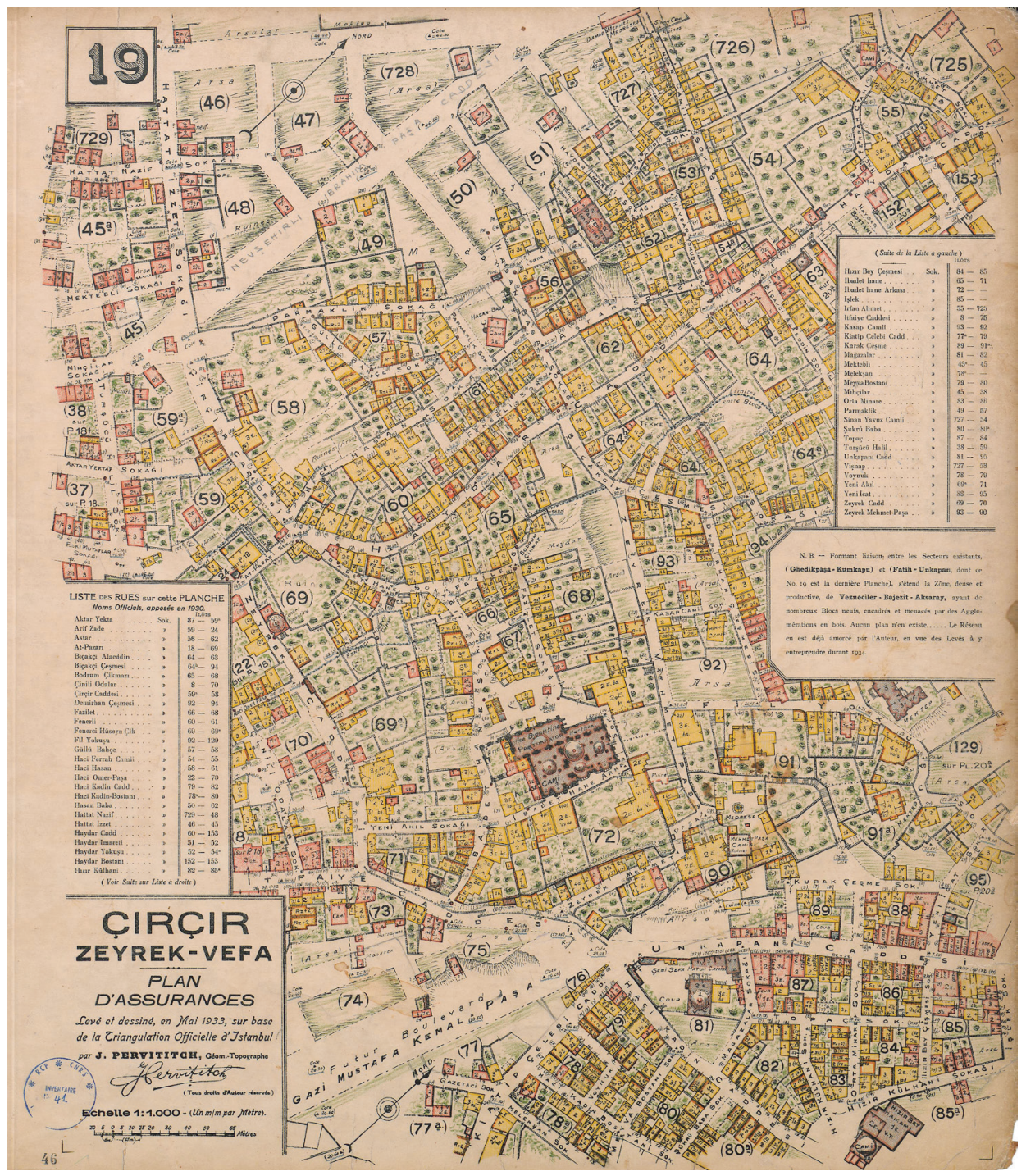

Resim 17. Zeyrek semti Pervititch haritas1

$1633,1660,1693,1718,1756,1833,1908$ ve 1918 yangınları Zeyrek semtini etkilemiş tarihi yangınlar olarak bilinmektedir. 1918 yangını semtin dokusunda epeyce bir zarara neden olsa da, halen ayakta olan evler, sokak dokuları ve çımazlar ile Zeyrek Dünya Miras Alanı bugüne ulaşmış önemli bir kentsel dokuya sahiptir. Alanda geleneksel dokunun yanısıra, özellikle 1980 sonrası dış göçlerle oluşan nüfus ihtiyaçlarını karşılamak üzere 4-5 katlı birçok betonarme apartman binası yapılmıştır. 
Osmanlı'nın büyük gezgini Evliya Çelebi, Seyahatname'sinin birinci cilt fihristinde Ayasofya'nın "eşkal" ve "üslub” una değindikten sonra "Evsâf-1 Küçük Ayasofya ve Zeyrek Câmi'i ve gayrılar" başlı̆̆ına yer verir. Fihristin ardarda gelen satırları şöyledir:

“- İslâmbol>un cemî‘i selâtin-i selef câmi'lerin ve vüzerâ ma“bedgâhların bildirir.

- Ayasofya'nın eşkâl-i tarz [u] tarhın ve binâ-yı musanna'âtı ve tûl' $[\mathrm{u}]$ arzın.

- Ayasofya makâmların ve Gülâbî Ağa sergüzeştin.

- Tetimme-i makâmât-1 Ayasofya ve hâssa-i Terlerdirek.

- Evsâf-1 Küçük Ayasofya ve Zeyrek Câmi'i ve gayrılar.

- Mi‘mârbaşı ile Ebü’l-feth'in mürâfa'a-1 şer'i ve Ebü’l-feth'in cemî‘i gazavâtların beyân eder." ${ }^{49}$

$\mathrm{Bu}$ başlıklandırmadan anlaşıldığ 1 üzere, herşeyden önce, Seyahatname'de Zeyrek Camii'ne Ayasofya'dan sonra müstakil bir başlık olarak yer verilip “Küçük Ayasofya ve Zeyrek Camii ve gayrılar” biçiminde daha görünür kılınması kuşkusuz mekanın/yapının öneminden kaynaklanmaktadır. Fakat bu önem, onun önemli bir Hristiyan mekânı ya da "müzehheb" bir kilise olmasının yanında, belki de daha çok, cesameti ve bir sed/püşte üzerindeki kent içi görünürlüğüyle ilgili gibidir. Başka bir ifadeyle, belli bir süre Ayasofya'nın camiye çevrilen tek kilise olduğu ve Fatih döneminde suriçi İstanbul'da yalnızca beş kilisenin camiye çevrildiği hesaba katılırsa, Zeyrek Cami'nin dönüştürülme motivasyonunun ilk sıralarında bir kilisenin camiye çevrilmesinden çok onun hacim olarak diğer kilise yapılarına göre nisbî büyüklüğü ve konum olarak görünür olmasının geldiği söylenebilir. Yukarıda da ifade edildiği gibi, Fatih dönemi devlet ricali bir kiliseyi camiye çevirmekten ziyade yeni cami yapımı konusunda "vazifeli" dirler.

Son derece görünür bir sed/püşte üzerinde ya da değerli bir tarihsel ve beşeri coğrafyada konumlanan, semtin en önemli yapısı Zeyrek Camii 17. yüzyıl yazarı Evliya Çelebi Seyahatname'sinin iç sayfalarında ise şöyle anlatılmaktadır (Vurgular yazara ait):

"Evsâf-1 Câmi'-i Zeyrekbaş1: Kostantîn'in (---) binâsıdır. Hazret-i Yahyâ rûhıyçün binâ olunmuş bir câmi'-i azîmdir kim zamân-1 nasârâda ismine Manastır-1 Sencovaniyye derlerdi..." ${ }^{{ }_{50}}$

49 Evliya Çelebi, Evliya Çelebi Seyahatnamesi, haz. Robert Dankof - Seyit Ali Kahraman - Yücel Dağl1, I. kitap, İstanbul, Yapı Kredi Yayınları, 2006, s. 1.

50 Evliya Çelebi, a.g.e., s. 60. 
"Hazret-i Yahyâ, Hazret-i Îsâ'nın vâlidesi tarafından akrabâ-yı karîbi olması ciheti ile Kostantîn'in vâlidesi bu Zeyrekbaşı'ndaki câmi'i inşâ edüp Hazret-i Yahyâ rûhuna hibe etdüğiyçün Manastır-1 Sencovaniyye derlerdi. Cânib-i erba'asına başka kal'a dîvârı ve bir su sarnıcı ve üç bin bıtrîke hücreler imâret edüp âbâdân etmişdi. Ba'de'l-feth Sultân Mehemmed câmi` etmişdir.

Sağîr ü kebîr cümle kırk altı kubbedir ve cümle (---) sütûn-1 zî-kıymetlerdir. Kıble kapusu'ndan tâ mihrâba varınca tûlu (---) ayakdır ve arzı (---) ayakdır. Ve bir minâre-i mevzûnu ve (---) kapusu vardır. Ammâ bu câmi‘ in kubbeleri ve toloz kemerleri içre mutallâ-yı müzehheb tasâvîr-i gûnâ-gûnlar var kim görenler vâlih [ü] hayran olur. Bir püşte üzre vâkı‘ olmuş cihânnümâ bir câmi'-i a'lâdır.

Ve'l-hâsıl Ebü'l-feth'in zamân-1 saltanatlarında İslâmbol içre kendüleri ve vüzerâları ve sâ'ir merâtib sâhibleri altı bin altı yüz yetmiş deyr-i kebîrlerin mihrâbların tahvîl edüp secdegâh-1 müslimîn edüp âyîn-i Muhammedî olup hâlâ amâristân câmi'lerdir." ${ }^{1}$

Evliya Çelebi, fetihten sonra "Âyîn-i Muhammedî” olan Zeyrek Camii'nin kilise halini bir başka yerde ise şöyle tasvir eder:

"Ve Kostantîn'in bir deyr-i mu'azzamı dahi İslâmbol'da Zeyrekbaşı nâm bir püşte-i âlî üzre Hazret-i Yahyâ aleyhi’s-selâm nâmına üç yüz altmış kubbeli bir manastır bünyâd edüp cânib-i erba'asına kal'a dîvârı-misâl bir rabât-1 kavî inşâ edüp içine üç bin ruhbân [u] huddâmân koyup âyîn-i Mesîhiyye ederlerdi.

Ve bu deyre muttasıl bir sahrîc inşâ edüp içine Kırkçeşme uyûnun cereyân etdirüp üzerine bir medâris-i incîlhâne bünyâd etdi." ${ }^{52}$

Evliya Çelebi’nin Zeyrek Cami hakkındaki bu tasvirleri ve bakış açısı manidar görünmektedir. Öncelikle, Zeyrek Cami’nin kubbe ve iç süslemelerinin kıymetini bilmekte ve görenlerin hayran olacağı derece güzellikte olduklarını önyarg1sız biçimde ifade etmektedir. Kuran-1 Kerim'de adı geçen hak peygamberlerden olan Hz. Yahya'yla kurduğu ilgi ve Müslüman bakış açısı mekanı sahiplenmekte ve kadim bir birikim olarak kendine ait kılmaktadır. Hatta bu bakış onun diline öylesine sinmiş olacak ki, “Kostantîn' in vâlidesi bu Zeyrekbaşı'ndaki câmi'i inşâ edüp" ifadesi son derece tabii bir şekilde yazılmıştır. "Kilise/kenise ifadesi yazılabilecekken "cami” yazılması tarihi mirasa bakışın önyargısız bir ifadesi gibidir. Zihinde böyle kurulan mekan, deyim yerindeyse kadim bir Müslüman mekan1na kolayca "tahvil" edilmiştir. Dolayısıyla "Âyîn-i Mesîhiyye" yapılan mekanın "âyîn-i Muhammedî” olmasında hiçbir sakınca görmez, hatta bir biçimde devam ettirilen bir kutsallığı vurgular. 
Zeyrek Cami'nden daha büyük, görkemli ve İstanbul'un tarihsel topografyasının en önemli nirengi noktalarının birini oluşturacak Fatih Külliyesi tamamlandıktan sonra medrese ağırlıklı işlevi Fatih Medreseleri’ne taşınmış olan "püşte" üzerindeki Zeyrek Cami, siluetteki etkisini nisbî olarak kaybettiği söylenebilir. Bu taşınma akabinde cami olarak işlevine devam etmiştir. Yavuz Selim ve Süleymaniye külliyeleri de İstanbul hayatındaki ve siluetindeki yerini alınca Zeyrek Cami, ölçek olarak küçük, konum ve görkem açısından mütevazı ama şehir ve mimari bakımından kıymetli bir tezyin unsuruna dönüşmüştür.

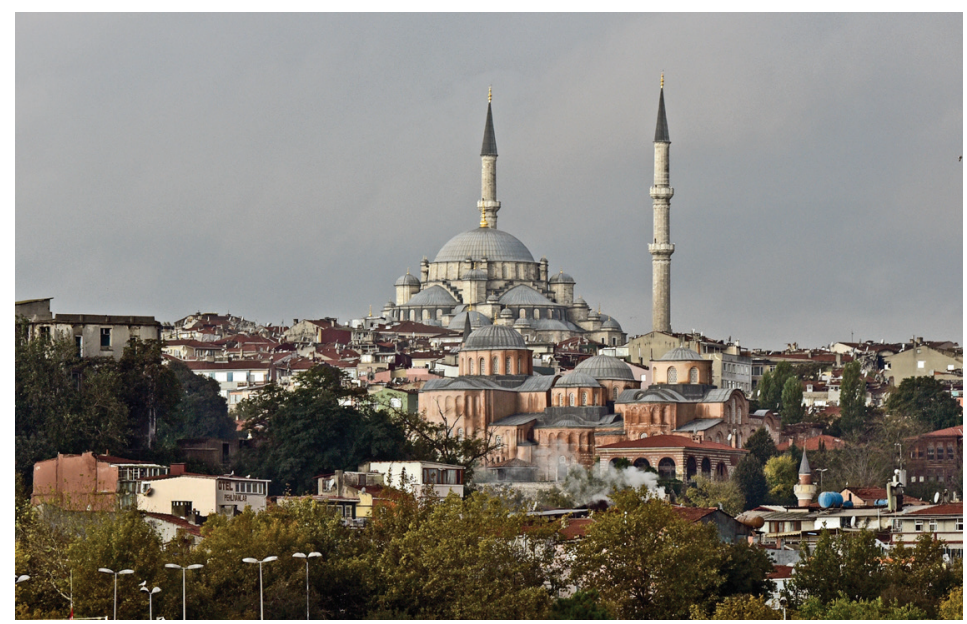

Resim 18. Zeyrek Cami ve Fatih Cami (F.: İhsan İlze)

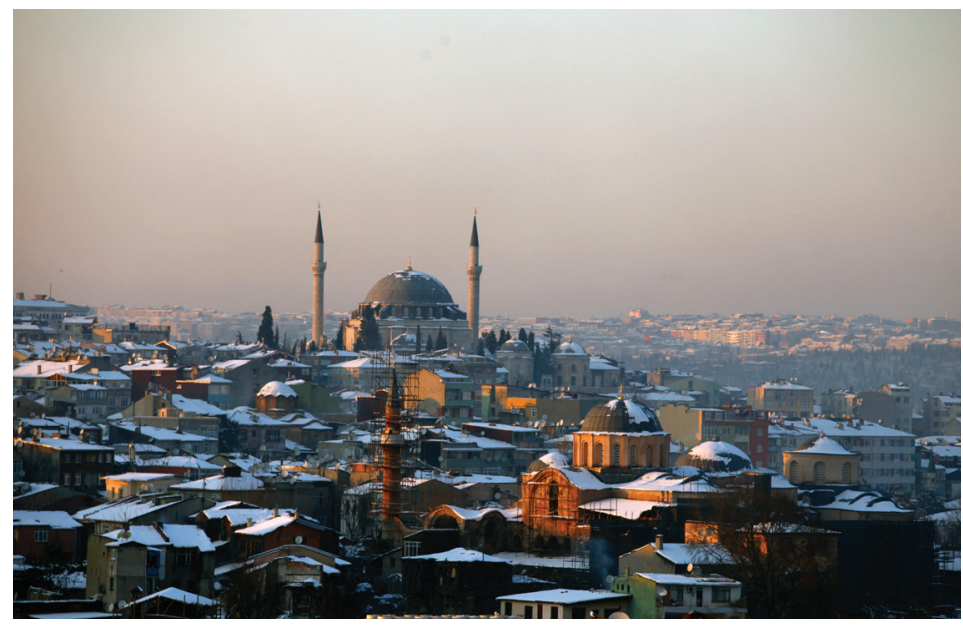

Resim 19. Zeyrek Cami ve Yavuz Selim Cami (F.: İhsan İlze) 


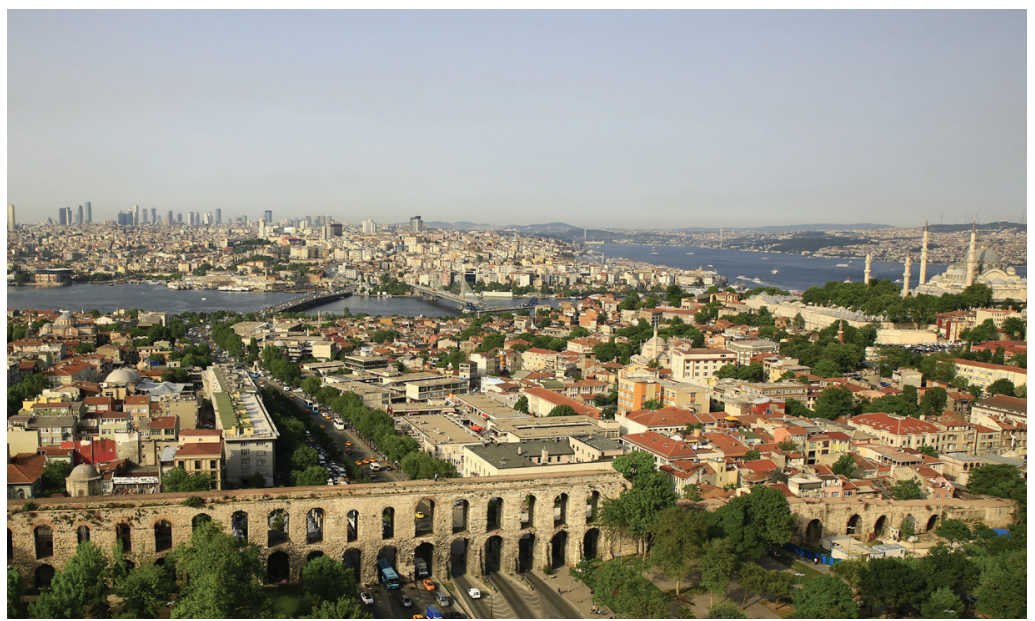

Resim 20. Zeyrek Cami ve Süleymaniye Cami (F.: İhsan İlze)

\section{Sonuç}

Tarihsel kaynaklardan ve modern literatürden elde edilen bilgilere göre bir kilisenin camiye dönüştürülme nedenleri şöyle sıralanabilir: Kiliseler bir gayr-i müslim memleketini fethetmenin sembolü olma; ilâhi nizamın yeniden tesisi; yeni fethedilen bir şehirde, yeni tesis edilen işlevlerin karşılanabilmesi; demografik yapı değişimlerine bağlı olarak, harap olan yapıların ihtiyaç doğrultusunda yeniden kullanımı. Bütün bu nedenlerin ağırlık oranları her yapı özelinde değişkenlik göstermektedir. Bugünkü bilgilerimize göre, ilgili literatürden ve araştırmalardan çıkarıldı ğı kadarıyla İstanbul'da halen ayakta olan, ismine ya da yaklaşık konumuna ulaşılabilen kırk adet kilise camiye çevrilmiştir. Her yapının dönüştürülme öyküsü birbirinden farklıdır. İstanbul'un fethi ile birlikte 1453'de kiliseden camiye, 24 Kasım 1934 tarihinde Bakanlar Kurulu kararı ile müzeye, Danıştay'ın bu kararı 2 Temmuz 2020'de iptal eden kararına isnad edilerek Cumhurbaşkanlığı Kararı ile 10 Temmuz 2020'de tekrar camiye dönüştürülen Ayasofya Cami ile Zeyrek Cami'nin öyküleri birbirinden farklıdır. Barındırdıkları alt öyküler bakımından Fenari İsa Cami ayrıca zikredilmelidir. Her yapıyla ilgili daha fazla ayrıntılı araştırmaya ihtiyaç vardır.

Teşekkür: Makaleyi okuyup görüşlerini bildiren İhsan Sarı, Murat Sav ve Hayri Fehmi Y1lmaz'a; bilgi ve fotoğraf desteğinden dolayı Murat Sav, İhsan İlze ve Coşkun Yılmaz'a; çizimlerde yardımcı olan Mehmet Enes Gülcan'a teşekkürü borç bilirim. 


\section{Kaynakça}

Başbakanlık Osmanlı Arşivi, Mühimme Defteri 62, nu. 209, s. 95 ve nu. 145, s. 65, tarih: Şevval 995.

Bölükbaşı, Atilla, Anılarda Trabzon, 2 cilt, Trabzon, Serander Yayınları, 2006.

Braudel, Fernand - vd., Akdeniz, Mekan ve Tarih, çev. N. İ. Erkurt, 2. bs., İstanbul, Metis Yayınları, 1995.

Cansever, Turgut, "Doğu ve Batı İlişkilerine Bir Bakış", Doğu Batı, sayı 2, 1998.

, Mimar Sinan, İstanbul, Albaraka Türk Yayınları, 2005.

Çelik, Zeynep, Değişen İstanbul: 19. Yüzyılda Osmanlı Başkenti, çev. S. Deringil, 2. bs., İstanbul, Tarih Vakfi Yurt Yayınları, 1998.

Diker, Hasan Firat, Ayasofya ve Onarımları, İstanbul, Fatih Sultan Mehmet Vakıf Üniversitesi Yayınları, 2016.

, “Ayasofya: Bir İktidar Öyküsü”, İnci Aslanoğlu için Bir Mimarlık Tarihi Dizimi, ODTÜ Yayınları, 2019.

Düzdağ, Ertuğrul, Şeyhülislam Ebussuûd Efendi Fetvaları Işı̆̆ında 16. Asır Türk Hayatı, İstanbul, 1972.

Ebussuud, Fetavâ, TSK, A. 786, varak 128a-b.

Emecen, Feridun, Imparatorluk Çă̆ının Osmanlı Sultanları I: Bayezid (II), Yavuz, Kanûnî, 3. bs., İstanbul, İSAM Yayınları, 2014.

Erdem, İlhan, "Türkiye Selçuklularında Fetih Metodu ve Uygulanışı", I. Uluslararası Selçuklu Kültür ve Medeniyet Kongresi Bildirileri, cilt 1, Konya, 2011.

Erdoğan, Esra Güzel, "Meryem Ana (Theotokos) Konstantinos Lips Manastırı Kilisesi (Fenari İsa Camii)", Antik Çă̆'dan XXI. Yüzyıla Büyük İstanbul Tarihi, bölüm ed. Halil İbrahim Düzenli, genel ed. Coşkun Yılmaz, cilt 8 (mimari), İstanbul, İSAM ve İBB Kültür A.Ş. Yayınları, 2015.

Erkal, Namık, "İstanbul'da Erken Dönem Osmanlı Mimarisi”, Antik Çağ'dan XXI. Yüzyıla Büyük İstanbul Tarihi, cilt 8 (mimari), bölüm ed. Halil İbrahim Düzenli, genel ed. Coşkun Yılmaz, İstanbul, İSAM ve İBB Kültür A.Ş. Yayınları, 2015.

Evliya Çelebi, Evliya Çelebi Seyahatnamesi, haz. Robert Dankof - Seyit Ali Kahraman - Yücel Dağlı, I. kitap, İstanbul, Yapı Kredi Yayınları, 2006. 
Eyüpgiller, Kemal Kutgün, “Atina Akropolü’nde Bir Cami”, Arredamento Mimarlık, sayı 173, 2004.

Eyice, Semavi, “İstanbul'un Camiye Çevrilen Kiliseleri”, TAÇ, cilt 1, say1 2, İstanbul, Türkiye Anıt Çevre Turizm Değerlerini Koruma Vakfı Yayını, 1986.

, "İstanbul'da Kiliseden Çevrilmiş Cami ve Mescidler ve Bunların Restorasyonu", Vakıflar Haftasl Dergisi, say1 7, 1990.

, “Ayasofya", İstanbul Ansiklopedisi, cilt 1, İstanbul, Tarih Vakfi Yayınlar1, 1993.

, "Eski İmaret Camii", İslam Ansiklopedisi, cilt 11, İstanbul, Türkiye Diyanet Vakfı Yayınları, 1995.

, “İstanbul'un Fethinde Bizans Mimarisi”, Eyüpsultan Sempozyumu VII, İstanbul, Eyüp Belediyesi Kültür ve Turizm Müdürlüğü Yayınları, 2003. , “Zeyrek Kilise Camii”, Dünden Bugüne İstanbul Ansiklopedisi, cilt 7, İstanbul, Tarih Vakfı Yurt Yayınları, 2003.

Fayda, Mustafa, "Fetih", İslam Ansiklopedisi, cilt 12, İstanbul, Türkiye Diyanet Vakfi, 1995.

Hasluck, Frederick William, Sultanlar Zamanında Hiristiyanlık ve İslam, çev. Timuçin Binder, cilt I, İstanbul, Ayrıntı Yayınları, 2012.

İnalc1k, Halil, “Ottoman Methods of Conquest”, Studia Islamic, cilt II, 1954. , "İstanbul: Bir İslam Şehri”, çev. İbrahim Kalın, İslam Tetkikleri Dergisi, İstanbul Üniversitesi Edebiyat Fakültesi Yayını, 1995.

$19,1999$.

, “Osmanlı’da Fetih Yöntemleri”, çev. H. C. Tuncer, Cogito, sayı

Kaplan, Michel, "Büyük Bir İmparatorluk Vakfi: Pantokrator (Zeyrek Cami)", Bizans: Yapılar, Meydanlar, Yaşamlar, ed. Annie Pralong, çev. Buket Kitapçı Bayrı, İstanbul, Kitap Yayınevi, 2011.

Karaman, Aykut - Önal, Şebnem, “Zeyrek”, Dünden Bugüne İstanbul Ansiklopedisi, cilt 7, İstanbul, Tarih Vakf1 Yurt Yayınları, 1994.

Kırımtayıf, Süleyman, Converted Byzantine Churches in İstanbul, İstanbul, Ege Yayınları, 2001.

, "Fatih Sultan Mehmed ve II. Bayezid Dönemlerinde Cami veya Mescide Dönüştürülen Bizans Yapıları”, Sanat Tarihi Defterleri 7, İstanbul, Ege Yayınlar1, 2003. 
Kiel, Machiel, “Atina”, İslam Ansiklopedisi, cilt 4, İstanbul, Türkiye Diyanet Vakfi Yayınları, 1991.

Kreiser, Klaus, "Zur Kulturgeschichte der osmanischen Moschee”, Türkische Kunst aus osmanischer Zeit, 2 c., Frankfurt am Main, 1985.

Kuban, Doğan, Osmanlı Mimarisi, İstanbul, Yapı Endüstri Merkezi Yayınları, 2007.

Müller-Wiener, Wolfgang, Istanbul'un Tarihsel Topografyası: 17. Yüzyıl Başlarına Kadar Byzantion-Konstantinopolis-İstanbul, çev. Ülker Sayın, İstanbul, Yapı Kredi Yayınları, 2001.

Necipoğlu, Gülru, Sinan Çă̆ı: Osmanlı Imparatorluğu’nda Mimari Kültür, çev. Gül Çağalalı Güven, İstanbul, İstanbul Bilgi Üniversitesi Yayınları, 2015.

, "The Life of an Imperial Monument: Hagia Sophia After Byzantum”, Hagia Sophia from the Age of Justinian to the Present, ed. R.Mark - A.Ş. Çakmak, Cambridge University Press, 1992.

Sav, Murat, "Sancaktar Hayrettin Mescidi”, Vakıflar Dergisi, sayı 33, 2010. ,"Mausoleion, Şapel ve Mescid Olarak Balabanağa", Vakif Restorasyon Ylllı̆ğ, sayı 2, 2011.

, “Tarihsel Süreçte İstanbul/Ayvansaray'daki Toklu İbrahim Dede Mescidi”, Vakıflar Dergisi, sayı 36, 2011.

, "Kazıs1-Projesi-İhya Süreci ve Koruma Prensipleri Açısından İsakapı Mescidi”, Bildiri Kitabı, Tarihi Yapıları Koruma ve Onarım Sempozyumu-TAYKON 2011 (26-29 Ekim 2011, YTÜ, İstanbul), 2011.

Stuart, James - Revett, Nicholas, The Antiquities of Athens (Measured and Delineated by James Stuart F.R.S. and F.S.A. and Nicholas Revett, Painters and Architects), vol. 2, London, John Nichols Publ., 1787.

Tuluk, Ömer İskender - Düzenli, Halil İbrahim - Düzenli, Evrim, “Osman11'da Fetih Sonrası Dinsel Mekânı Camileştirme Anlayış1: Trabzon Örneği (14611665)", Trabzon Kent Mirası: Yer Yapı Hafiza, ed. Ömer İskender Tuluk - Halil İbrahim Düzenli, İstanbul, Klasik Yayınları, 2010.

Yerasimos, Stefanos, "Kostantiniyye Kiliselerinden İstanbul Camilerine Bir Değişimin Tarihi”, Bizans: Yapılar, Meydanlar, Yaşamlar, ed. Annie Pralong, çev. Buket Kitapçı Bayrı, İstanbul, Kitap Yayınevi, 2011.

Y1lmaz, Coşkun, ed., Antik Çağ'dan XXI. Yüzyıla Büyük İstanbul Tarihi, cilt 1-10, İstanbul, İSAM ve İBB Kültür AŞ. Yayınları, 2015. 
